\title{
Oligodendrocytes Are Targets of HIV-1 Tat: NMDA and AMPA Receptor-Mediated Effects on Survival and Development
}

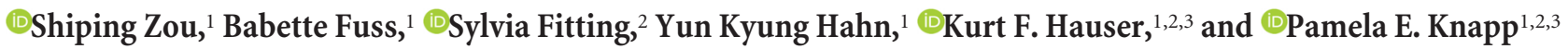 \\ ${ }^{1}$ Department of Anatomy and Neurobiology, ${ }^{2}$ Department of Pharmacology and Toxicology, and ${ }^{3}$ Institute for Drug and Alcohol Studies, Virginia \\ Commonwealth University School of Medicine, Richmond, Virginia 23298
}

Myelin pallor in $\mathrm{HIV}^{+}$individuals can occur very early during the disease process. While myelin damage might partly originate from HIV-induced vascular changes, the timing suggests that myelin and/or oligodendrocytes (OLs) may be directly affected. Histological (Golgi-Kopsch, electron microscopy) and biochemical studies have revealed an increased occurrence of abnormal 0L/myelin morphology and dysregulated myelin protein expression in transgenic mice expressing the HIV-1 transactivator of transcription (Tat) protein. This suggests that viral proteins by themselves might cause OL injury. Since Tat interacts with NMDARs, we hypothesized that activation of NMDARs and subsequent disruption of cytoplasmic $\mathrm{Ca}^{2+}\left(\left[\mathrm{Ca}^{2+}\right]_{\mathrm{i}}\right)$ homeostasis might be one cause of white matter injury after HIV infection. In culture, HIV-1 Tat caused concentration-dependent death of immature OLs, while more mature OLs remained alive but had reduced myelin-like membranes. Tat also induced $\left[\mathrm{Ca}^{2+}\right]_{\mathrm{i}}$ increases and Thr-287 autophosphorylation of $\mathrm{Ca}^{2+} /$ calmodulin-dependent protein kinase II $\beta$ (CaMKII $\beta$ ) in OLs. Tat-induced $\left[\mathrm{Ca}^{2+}\right]_{\mathrm{i}}$ was attenuated by the NMDAR antagonist MK801, and also by the AMPA/ kainate receptor antagonist CNQX. Importantly, both MK801 and CNQX blocked Tat-induced death of immature OLs, but only MK801 reversed Tat effects on myelin-like membranes. These results suggest that OLs can be direct targets of HIV proteins released from infected cells. Although viability and membrane production are both affected by glutamatergic receptor-mediated $\mathrm{Ca}^{2+}$ influx, and possibly the ensuing CaMKII $\beta$ activation, the roles of AMPARs and NMDARs appear to be different and dependent on the stage of OL differentiation.

Key words: calcium; HIV; neuroAIDS; NMDA; oligodendrocyte; Tat

Significance Statement

Over 33 million individuals are currently infected by HIV. Among these individuals, $\sim 60 \%$ develop HIV-associated neurocognitive disorders. Myelin damage and white matter injury have been frequently reported in HIV patients but not extensively studied. Clinical studies using combined antiretroviral therapy (cART) together with adjunctive "anti-inflammatory" drugs show no improvement over cART alone, suggesting existence of injury mechanisms in addition to inflammation. In our studies, oligodendrocytes exhibited rapid increases in intracellular $\mathrm{Ca}^{2+}$ level upon HIV-1 transactivator of transcription (Tat) exposure. Thus, immature and mature oligodendrocytes can be direct targets of Tat. Since ionotropic glutamate receptor antagonists can partially or fully reverse the detrimental effects of Tat, glutamate receptors could be a potential therapeutic target for white matter damage in HIV patients.

\section{Introduction}

Although combined antiretroviral therapy (cART) dramatically decreases mortality and neurological deficits, $60 \%$ of the HIV-

Received Nov. 19, 2014; revised July 2, 2015; accepted July 13, 2015.

Author contributions: S.Z., B.F., K.F.H., and P.E.K. designed research; S.Z. and Y.K.H. performed research; S.Z.,

S.F., Y.K.H., and P.E.K. contributed unpublished reagents/analytic tools; S.Z., B.F., S.F., K.F.H., and P.E.K. analyzed data; S.Z., K.F.H., and P.E.K. wrote the paper.

This work was supported by the National Institutes of Health [Grants F31 NS084838 (S.Z.), R21 NS069216 (P.E.K.), and K02 DA027374 (K.F.H.)]. Some fluorescent microscopy was performed at the Virginia Commonwealth University Department Anatomy and Neurobiology Microscopy Facility, supported in part with funding from National Institutes of Health-National Institute of Neurological Disorders and Stroke Center Core Grant 5P30NS047463. infected population still experience HIV-associated neurocognitive disorders (HAND; Williams et al., 2009; Power et al., 2012). Despite viral suppression, infected brain cells, including microglia and astrocytes, continuously express and secrete viral proteins. HIV-1 transactivator of transcription (Tat) is a highly

The authors declare no competing financial interests.

Correspondence should be addressed to Pamela E. Knapp, PhD, Department of Anatomy and Neurobiology,

Virginia Commonwealth University, PO Box 980709, Richmond, VA 23298-0709. E-mail: peknapp@vcu.edu.

S. Fitting's present address: Department of Psychology, University of North Carolina, Chapel Hill, NC 27599

DOI:10.1523/JNEUROSCI.4740-14.2015

Copyright $\odot 2015$ the authors $\quad 0270-6474 / 15 / 3511384-15 \$ 15.00 / 0$ 
conserved HIV protein that can be detected in blood (Xiao et al., 2000), extracellular matrix (Urbinati et al., 2005a), and CSF (Wang et al., 2014) in $\mathrm{HIV}^{+}$individuals, even with cART (Johnson et al., 2013). In addition to its essential role in viral replication and efficient viral gene transcription, Tat has also been shown to be a toxic factor in the CNS that leads to glial inflammatory responses (Nath et al., 2000; El-Hage et al., 2006, 2008a) and neuronal cell death (Zou et al., 2011; Rumbaugh et al., 2013).

Oligodendrocytes (OLs) are myelinating CNS cells. OL dysfunction can lead to abnormal myelination, impaired neuronal signaling, and axon degeneration, resulting in serious neurological deficits. OLs do not express the CD4 receptor, which is the main cellular receptor for HIV entry (Sattentau et al., 1986). However, OLs from postmortem HIV-infected tissues show upregulated expression of p53 and BAX (Jayadev et al., 2007), indicating activation of death pathways. Early studies using Tat transgenic mice showed that OLs exhibit caspase-3 activation and decreased process length when Tat expression was induced for $7 \mathrm{~d}$ (Hauser et al., 2009), suggesting that Tat may affect OL morphology and function in vivo.

OL lineage cells express functional ionotropic glutamate receptors (iGluRs), including AMPARs and NMDARs, both in vivo and in vitro (Káradóttir et al., 2005; Salter and Fern, 2005; Micu et al., 2006; Alix and Fern, 2009). The expression of these receptors on OLs is highly heterogeneous. Individual cells express different levels of iGluRs, and the distribution, subunit components, and downstream signaling pathways of different iGluRs may vary (Káradóttir et al., 2005; Matute et al., 2006; Micu et al., 2006). Adding further complexity, iGluR expression in OLs is also developmentally regulated. AMPARs are expressed at all developmental stages, while NMDARs show later expression (Salter and Fern, 2005). In addition, the majority of NMDARs expressed on OLs are clustered on processes and the myelin sheath while AMPARs are evenly distributed on the cell body (Micu et al., 2006). Activation of iGluRs results in immature OL death (Deng et al., 2003; Follett et al., 2004) and myelin disruption (Micu et al., 2006). Importantly, since OL NMDARs are less susceptible to $\mathrm{Mg}^{2+}$ blockade (Káradóttir et al., 2005), and OL AMPARs lack the $\mathrm{Ca}^{2+}$-impermeable GluR2 subunit (Hollmann and Heinemann, 1994; Matute et al., 2002), the level of extracellular glutamate necessary to injure OLs may be much lower than required for excitotoxic neuronal injury.

Using the Golgi-Kopsch procedure, we observed an increased occurrence of OLs with aberrant morphology in the corpus callosum and anterior commissure of transgenic mice expressing HIV-1 Tat. Electron microscopy (EM) also demonstrated disrupted myelin structure in the caudate-putamen. In Western blots of tissues from the same mice, myelin protein expression was abnormal. Since Tat-induced activation of iGluRs and resulting $\mathrm{Ca}^{2+}$ influx cause neuronal injury (King et al., 2006; Kim et al., 2008), we hypothesized a similar mechanism for OLs. Increased cytoplasmic $\mathrm{Ca}^{2+}\left(\left[\mathrm{Ca}^{2+}\right]_{\mathrm{i}}\right)$ and $\mathrm{Ca}^{2+} /$ calmodulindependent protein kinase II $\beta$ (CaMKII $\beta)$ activation occurred in immature and mature OLs with Tat treatment; both were attenuated by NMDAR and AMPA/kainate receptor (AMPA/KAR) antagonists. Additionally, Tat caused immature OL death and reduced myelin-like membrane production by mature OLs, both in a dose-dependent manner. Both effects were blocked by MK801, while CNQX only blocked immature OL death. Thus, iGluRs are potential mediators of HIV-induced white matter (WM) damage through CaMKII $\beta$ activation. Since these experiments were performed using a highly purified OL culture model, the effects likely reflect direct actions of Tat, rather than a response to Tat-induced inflammation.

\section{Materials and Methods}

All experiments involving animals were performed in compliance with procedures reviewed and approved by the Virginia Commonwealth University Institutional Animal Care and Use Committee.

Tat transgenic mice and in vivo Tat expression. Experiments used a transgenic mouse engineered to inducibly express HIV- $1_{\text {IIIB }}$ Tat $_{1-86}$. Tat expression is controlled by a tet responsive element, whose activation is controlled by a reverse tetracycline transactivator ( $r T A$ ) transgene driven by a human glial fibrillary acidic protein (GFAP) promoter (Hauser et al., 2009; Hahn et al., 2012). Within the CNS, Tat expression is induced in astroglia by administration of doxycycline (DOX). HIV transgenic $\left(\mathrm{Tat}^{+}\right.$) and Tat ${ }^{-}$control littermates were fed DOX-containing chow (6 g/kg; Harlan Laboratories) ad libitum to induce expression of Tat. Both acute and chronic time periods were chosen for Tat induction to visualize early changes in OL processes (Golgi impregnation, $7 \mathrm{~d}$ ) that might precede later myelin changes (EM, 12 weeks) in Tat ${ }^{+}$mice. The Tat $^{-}$mice express rtTA but not Tat and are a control for possible effects of the foreign transcription factor. The expression of the rtTA transgene in Tat ${ }^{-}$mice and $r t T A$ and Tat transgenes in $\mathrm{Tat}^{+}$mice was confirmed by genotyping. While our studies were not designed to determine whether defects were specific to particular regions, we observed OL and myelin injury in three different CNS regions: caudate-putamen (observed by EM), corpus callosum (observed by Golgi impregnation), and anterior commissure (observed by Golgi impregnation).

Oligodendroglial cultures. Primary cultures were prepared from mice (CD-1, Charles River Laboratory) of both sexes at postnatal day 0-1 as previously published (Zou et al., 2011). In brief, whole brains were dissected and minced before being incubated $\left(37^{\circ} \mathrm{C}, 5 \% \mathrm{CO}_{2}\right)$ with $2.5 \mathrm{mg} / \mathrm{ml}$ trypsin (Sigma-Aldrich) and $0.015 \mathrm{mg} / \mathrm{ml}$ DNase (SigmaAldrich) in DMEM (Life Technologies) for $30 \mathrm{~min}$. Tissue was triturated and resuspended in DMEM supplemented with $10 \%$ fetal bovine serum (Thermo Scientific Hyclone), 6 g/L glucose (SigmaAldrich), sodium bicarbonate, and penicillin/streptomycin (Life Technologies), filtered through nylon mesh with pore sizes 100 and $40 \mu \mathrm{m}$, and then plated in T25 flasks (Corning) precoated with polyL-lysine ( $1 \mathrm{mg} / \mathrm{ml}$; Sigma-Aldrich) at a density of 2 brains/flask.

At day 8 , primary glial cultures were put on an orbital shaker $(100$ $\mathrm{rpm}, 20 \mathrm{~min}$ ) to dislodge microglia loosely attached to the culture surface. Medium was replaced and the flasks were hit sharply against the table 5-10 times to release as many O2A/glial progenitor cells as possible. The suspension was panned on a plastic, nontissue culture dish for $2 \mathrm{~h}$ to remove adherent astroglia and microglia. Progenitors were plated in serum-free medium supplied with $10 \mathrm{ng} / \mathrm{ml} \mathrm{CNTF}$ (Peprotech), $5 \mu \mathrm{g} / \mathrm{ml} \mathrm{N}$-acetyl-L-cysteine (Sigma-Aldrich), and 15 nM triiodothyronine (Sigma-Aldrich) on culture surfaces coated with poly-L-lysine as described above. Medium was changed every $3 \mathrm{~d}$.

Viral protein and receptor antagonist treatments. OL cultures were treated with HIV-1 Tat ${ }_{1-86}$ (clade B, ImmunoDX) at 1, 10, or $100 \mathrm{~nm}$ \pm MK801 (20 $\mu \mathrm{M}$; Tocris Bioscience) and CNQX (20 $\mu \mathrm{M}$; Tocris Bioscience), at day 2 or 7 after plating the enriched cultures. In selected studies, heat-inactivated Tat ${ }_{1-86}$ was used as a control. If the cells were treated concurrently with Tat and MK801 or CNQX, the receptor antagonists were added $30 \mathrm{~min}$ before Tat.

The concentrations of Tat used in our experiments (1-100 nM) are a reasonable approximation of titers in HIV-infected brains. The serum Tat concentration in HIV patients is between 2 and $40 \mathrm{ng} / \mathrm{ml}$ (Xiao et al., 2000). Tat has a high affinity for cell-surface proteins (e.g., heparin sulfate proteoglycan; Liu et al., 2000) and extracellular cellular matrix components (e.g., glycosaminoglycans; Xiao et al., 2000). Portions of cells adjacent to productively infected cells may be subjected to higher levels of Tat within the restricted confine of the extracellular space. Further, the potency of recombinant Tat, as used in our experiments, has been reported to be much less than that of secreted Tat (Li et al., 2008). 
MK801 and CNQX concentrations were chosen to maximally block the NMDAR and AMPA//KAR, respectively, as previously reported (Salter and Fern, 2005). Nimodipine $(10 \mu \mathrm{M})$, dantrolene $(10 \mu \mathrm{M})$, DLthreo- $\beta$-benzyloxyaspartate (DL-TBOA; $100 \mu \mathrm{M})$, RS102895 (10 $\mu \mathrm{M}$ ), SB328437 $(10 \mu \mathrm{M})$, and the arginyl-glycyl-aspartyl-serine (RGDS) peptide (10 $\mu \mathrm{M}$; all from Tocris Bioscience) were used when assessing effects of different inhibitors on Tat-induced $\left[\mathrm{Ca}^{2+}\right]_{\mathrm{i}}$ change in OLs and were added 20 min before Tat treatment and $\mathrm{Ca}^{2+}$ imaging.

Time-lapse analysis of individual OLs. Enriched immature OLs were plated on a 12-well plate at a density of $1.5 \times 10^{4}$ cells/well. After Tat \pm MK801/CNQX treatment, the plate was transferred to a Heating Insert M12 (PeCon) and put on the scanning stage of a Zeiss Axio Observer Z1 microscope (Carl Zeiss Microscopy) equipped with an environmental incubator (PeCon) that keeps a constant temperature $\left(37^{\circ} \mathrm{C}\right)$ and $\mathrm{CO}_{2}$ level (5\%) during the experimental period. Both the heating insert and the environmental incubator were prewarmed to $37^{\circ} \mathrm{C} \geq 1 \mathrm{~h}$ before the start of the experiment. For each treatment, $>25$ OLs were systematically yet arbitrarily chosen, and repeatedly imaged every hour using an automated stage controlled by the Zeiss Axiovision 4.8 software (Carl Zeiss). Viability of cells was confirmed at the end of each experiment using calcein-acetoxy methylester (calcein-AM; Life Technologies) staining. Time of cell death was determined by carefully assessing all preselected OLs in hourly digital images, using rigorous morphological criteria, including but not restricted to (1) loss of phase brightness, (2) degenerating processes, and (3) involution or fragmentation of cell soma. Data were analyzed at $4 \mathrm{~h}$ intervals and presented as mean percentage of survival \pm SEM from $\geq 4$ individual experiments $(n \geq$ $4 ; \geq 25$ cells analyzed per treatment, per N). Repeated-measures ANOVA and post hoc Bonferroni's test were used to compare whether differences between treatments were significant $(p \leq 0.05)$ or not significant $(p>0.05)$.

Live-dead assay. Cell viability after Tat treatment was confirmed using the LIVE/DEAD Viability/Cytotoxicity Kit (Life Technologies). To make the working solution, $20 \mu \mathrm{l}$ of $2 \mathrm{~mm}$ ethidium homodimer-1 (EthD-1) stock solution and $5 \mu \mathrm{l}$ of $4 \mathrm{~mm}$ calcein-AM stock solution were added to $10 \mathrm{ml}$ of sterile, tissue culture-grade Dulbecco's modified PBS (D-PBS) sequentially and vortexed for $20 \mathrm{~s}$. Five hundred microliters of working solution were added to each well of a sterile 24 -well plate. OLs were plated on 12-mm-diameter German glass coverslips (Chemglass Life Sciences) and treated with vehicle or $100 \mathrm{~nm}$ Tat for 24,48 , and $72 \mathrm{~h}$. After treatment, coverslips were quickly rinsed in D-PBS once and transferred to individual wells of a 24 -well plate to incubate in working solution (30 $\mathrm{min}$, room temperature). Coverslips were then carefully inverted onto a clean Fisherbrand Superfrost Plus Gold microscope slide (Fisher Scientific) with $10 \mu \mathrm{l}$ of fresh D-PBS and sealed with clear fingernail polish. Fluorescent (excitation/emission wavelengths: $\sim 495 / \sim 515 \mathrm{~nm}$ for calcein-AM; $\sim 528 / \sim 617 \mathrm{~nm}$ for EthD-1) and phase images were taken using a Zeiss Axio Observer Z1 microscope with Zeiss Axiovision 4.8 software (Carl Zeiss). Live or dead cells were defined by green (calcein$\mathrm{AM}$ ) or red (EthD-1) fluorescence, respectively. For each $n$ (individual experimental group), 20 images were systematically, yet arbitrarily taken and analyzed, and the relative ratio of live/dead cells was quantified by numbers of green/red fluorescent pixels using ImageJ software (National Institutes of Health).

Intracellular calcium assessment. After 2 or $7 \mathrm{~d}$ culture, OLs plated on $35 \mathrm{~mm}$ glass-bottom culture dishes (MatTek) were loaded with $2.5 \mu \mathrm{M}$ fura-2-AM (Life Technologies) for $30 \mathrm{~min}$ at $37^{\circ} \mathrm{C}$. Cells were washed twice and incubated in DMEM for another $30 \mathrm{~min}$ to ensure deesterification of the AM group before transfer to the environmental incubator of the Zeiss Axio Observer microscope. Cytosolic $\mathrm{Ca}^{2+}$ concentration was assessed using the physiology module of the AxioVision software. Fura-2-AM was excited at 340 and $380 \mathrm{~nm}$, and emissions collected at 510-540 nm. Data were collected every second for the first $90 \mathrm{~s}$, then every $5 \mathrm{~s}$ for the next minute, then every $30 \mathrm{~s}$ for the rest of the 20 min experimental period. The F340/F380 ratio was converted to calcium concentration via a standard curve generated using a calcium calibration buffer kit (Life Technologies). Data were presented as mean $\left[\mathrm{Ca}^{2+}\right]_{\mathrm{i}} \pm$ SEM from $\geq 4$ individual experiments $(>25$ cells analyzed per $n$ ).
CM-DiI live staining. Cells from day 8 primary cultures were plated on $35 \mathrm{~mm}$ glass-bottom culture dishes $\left(1.5 \times 10^{4} \mathrm{cells} /\right.$ dish $)$ and incubated for $6 \mathrm{~d}$ in growth medium as described above. Two micrograms per milliliter of CM-DiI (Life Technologies) was added to the medium, and cells were incubated for $5 \mathrm{~min}$ before being transferred to $4^{\circ} \mathrm{C}$ for another $15 \mathrm{~min}$. Cells were washed with prewarmed culture medium and placed back in the incubator. Treatments were applied the next day, before placement in the stage incubator. Individual OLs were selected as described in the repeated-measure paradigm. Fluorescent (excitation, $560 / 40 \mathrm{~nm}$; emission, 630/75 nm) and phase images were taken at 0, 24, and $48 \mathrm{~h}$ after treatment. The membrane area of individual cells, defined as the total red fluorescent area surrounding the cell body minus the area of the cell body (Dennis et al., 2008), was quantified using IPLab imaging software (BD Biosciences).

Immunostaining. Cells cultured on glass coverslips were fixed with $4 \%$ paraformaldehyde and permeabilized with Triton X-100. Neurons, astroglia, microglia, and OLs, were identified with antibodies specific to microtubule-associated protein 2 (1:1000; Abcam), GFAP (1:1000; Millipore), ionized calcium-binding adaptor molecule 1 (1:500; Wako Chemicals), and myelin basic protein (MBP, 1:1000; Abcam), and the O4 monoclonal antibody [grown in our laboratory from hybridoma cells (Knapp and Hauser, 1996), 1:20], respectively. Antibodies specific to $\alpha \mathrm{v}$ or $\beta 3$ subunits (1:1000; Abcam) were used to identify integrins on OLs. Corresponding secondary antibodies were conjugated to Alexa 488 and 594 (1:2000; Life Technologies). Cell nuclei were visualized with Hoechst 33342 dye (1:2000; Life Technologies); coverslips were mounted with Prolong Gold Antifade reagent (Life Technologies). Images were acquired using a Zeiss LSM 700 laser scanning confocal microscope and processed using the maximum projection module of Zen 2010 software (Carl Zeiss) to show cells in their entirety.

Western blotting. Day 2 or 7 OLs were treated with vehicle or Tat for $30 \mathrm{~min}$. Proteins from treated cells were extracted using RIPA buffer (Sigma-Aldrich) with protease and phosphatase inhibitors (Thermo Scientific). Striatal tissue from Tat transgenic mice was homogenized with three strokes ( $15 \mathrm{~s} /$ stroke) in a $2 \mathrm{ml}$ ceramic bead tube (MO BIO Laboratories) using a Precellys 24 Homogenizer (Bertin Technologies) before protein extraction using RIPA buffer with protease and phosphatase inhibitors. The concentration of extracted proteins was assessed using the BCA assay (Thermo Scientific) before lysates were mixed at 1:1 ratio with $2 \times$ Laemmli buffer (Bio-Rad). Equal amounts of total protein $(5-10 \mu \mathrm{g})$ from each sample were loaded on Criterion $4-20 \%$ SDS-polyacrylamide gels (Bio-Rad) and electrophoretically separated under constant voltage $(130 \mathrm{~V})$ for $1.5 \mathrm{~h}$. Proteins were then transferred onto polyvinylidene difluoride membranes (Bio-Rad) with constant current $\left(0.6 \mathrm{~A}, 2 \mathrm{~h}, 4^{\circ} \mathrm{C}\right)$. After transfer, membranes were blocked in $0.1 \%$ casein solution (Bio-Rad; $1 \mathrm{~h}$, room temperature) before probing with primary antibodies for MBP (1:5000; Abcam), myelin associated glycoprotein (MAG, 1:3000; Abcam), phospho-CaMKII (1:1000; Abcam), CaMKII $\beta$ (1:1000; Life Technology), and glyceraldehyde 3-phosphate dehydrogenase (1:3000; Abcam) at $4^{\circ} \mathrm{C}$ overnight. Membranes were incubated with appropriate IRDye secondary antibodies (1:3000; Li-COR) for $1 \mathrm{~h}$ at room temperature, and imaged using an Odyssey Imager (Li-COR). Protein bands were quantified using Li-COR image studio software. The phospho-CaMKII antibody binds both phospho-CaMKII $\alpha$ and phospho-CaMKII $\beta$, but not phospho-CaMKII $\gamma$ or phosphoCaMKII $\delta$. Phosphor-CaMKII $\alpha(\sim 50 \mathrm{kDa})$ and phosphor-CaMKII $\beta$ $(\sim 60 \mathrm{kDa})$ can be easily identified on the blot by their different sizes.

$E M$. Tissue processing and EM were performed as previously published (Hahn et al., 2012). In brief, Tat $^{+}$mice fed with DOXcontaining chow for 3 months were perfused with phosphate buffer, pH 7.4 (Sigma-Aldrich), containing 2\% paraformaldehyde and $2 \%$ glutaraldehyde before fixation/staining in $1 \%$ osmium tetroxide for $1 \mathrm{~h}$. Fixed tissues were dehydrated through graded ethanols and infiltrated overnight in Embed 812 (Electron Microscopy Sciences), then polymerized at $60^{\circ} \mathrm{C}$ for $2 \mathrm{~d}$. Tissue blocks were sectioned at $600-700$ $\AA$ thickness on a Leica EM UC6i ultramicrotome (Leica Microsystems), collected onto formvar-coated grids, and stained with uranyl acetate (5\%) and Reynolds's lead citrate (Reynolds, 1963). EM images 

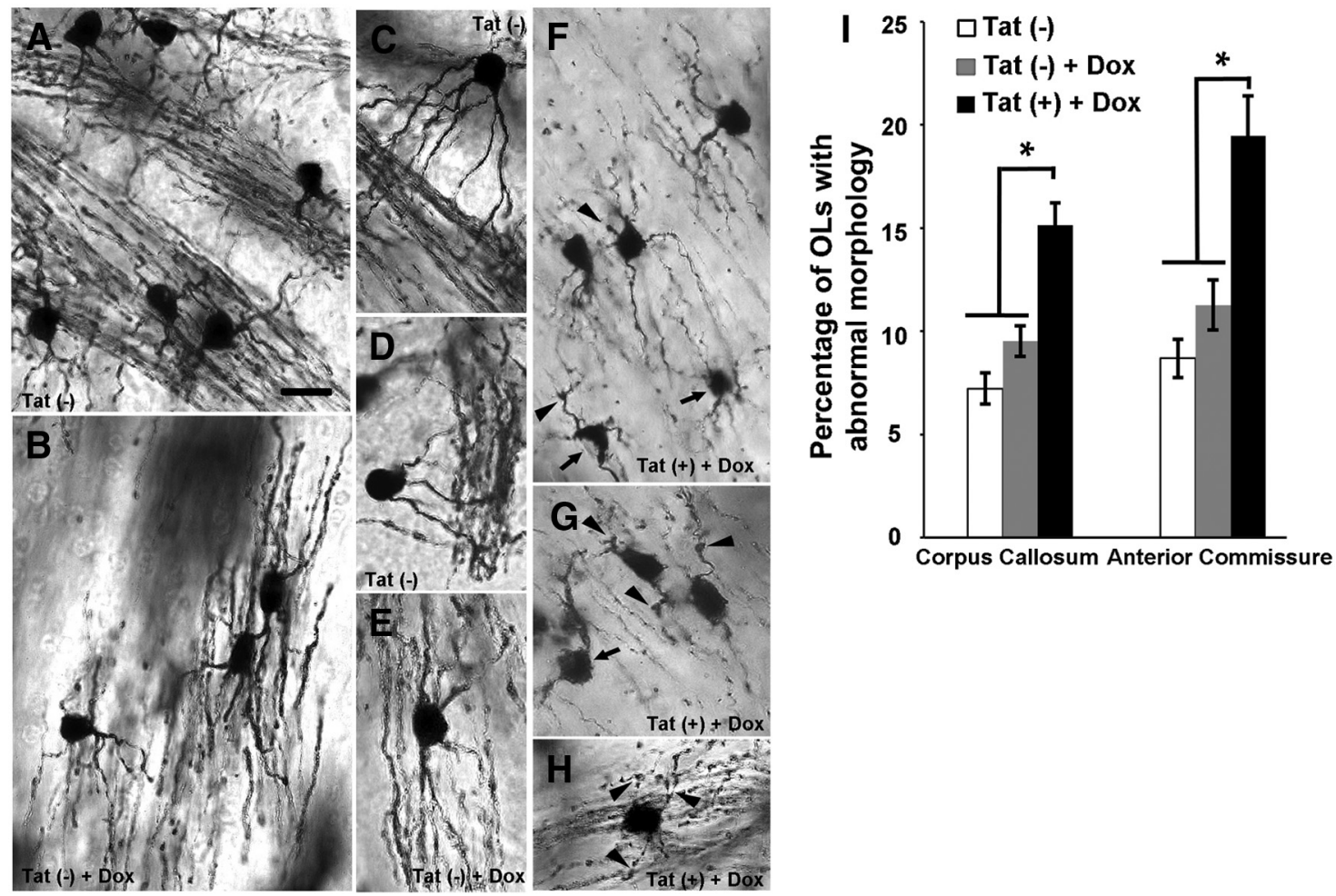

Figure 1. Tat induces aberrant $0 \mathrm{~L}$ morphology in vivo. Golgi-Kopsch impregnation was used to visualize the structure of $0 \mathrm{Ls}$ in Tat ${ }^{-}$mice receiving normal chow, and in Tat ${ }^{-}$and Tat ${ }^{+}$mice fed DOX-containing chow for $7 \mathrm{~d}$. $\boldsymbol{A}-\boldsymbol{H}$, Sample bright-field images are labeled with the genotype and treatment. $\boldsymbol{A}-\boldsymbol{E}$, The majority of $0 \mathrm{Ls}$ from corpus callosum and anterior commissure of Tat ${ }^{-}$ mice fed normal or DOX-containing chow show normal morphology. These OLs have small ( $\sim 10 \mu \mathrm{m}$ diameter) cell bodies with smooth edges and relatively thick and continuous processes extending from their cell body to the WM tracts. $\boldsymbol{F}-\boldsymbol{H}$, Although most $0 \mathrm{Ls}$ in DOX-induced Tat ${ }^{+}$mice appear normal, a significantly higher percentage had an aberrant phenotype. These $0 \mathrm{Ls}$ exhibited abnormal varicosities along or at the end of their processes (arrowheads), thin and disrupted processes, and irregular cell bodies (arrows). I, Quantification of OLs with abnormal morphology in corpus callosum and anterior commissure of Tat ${ }^{-}$and Tat ${ }^{+}$mice. In both regions, Tat induction resulted in significantly more $0 \mathrm{Ls}$ with pathological phenotype $\left({ }^{*} p<0.05 ; 1\right.$-way ANOVA followed by post hoc Bonferroni's test; $n=4$ individual experiments; $\geq 40$ cells were counted for each $n$; Scale bar, $10 \mu \mathrm{m}$ for all images).

were taken on a JEOL JEM-1230 Transmission Electron Microscope (JEOL USA) at 10,000-200,000 × magnification using a Gatan Ultrascan 4000 digital camera with DigitalMicrograph software (Gatan).

Golgi-Kopsch impregnation. Twelve-week-old Tat transgenic mice received normal $\left(\mathrm{Tat}^{-}\right)$or DOX-containing chow $\left(\mathrm{Tat}^{-}\right.$and $\mathrm{Tat}^{+}$) for 7 d. A modified Golgi-Kopsch procedure as previously published (Hauser et al., 1989) was used to randomly impregnate neurons and glia. In brief, mice were anesthetized by isoflurane inhalation and euthanatized by intracardiac perfusion with $2 \%$ potassium dichromate and $5 \%$ glutaraldehyde. Whole forebrains were taken out and immersed in perfusion solution for $5 \mathrm{~d}$ before being rinsed and replaced in aqueous $0.75 \%$ silver nitrate solution for another $5 \mathrm{~d}$. After that, tissues were infiltrated with graded sucrose solutions containing $0.75 \%$ silver nitrate for $24 \mathrm{~h}$ and frozen on dry ice before cutting into $120-\mu \mathrm{m}$-thick serial coronal sections and thaw-mounting onto Superfrost-Plus slides (Fisher). Fluid to tissue volume ratios were $\geq 50: 1$, and nonmetallic devices were used throughout. Images of impregnated OLs were taken randomly from corpus callosum and anterior commissure. Impregnated OLs were identified using strict morphological criteria including small $(\sim 10 \mu \mathrm{m}$ diameter) cell body, myelin-forming processes aligned parallel to WM tracts, and appropriate localization. For each experimental condition ( Tat $^{-}$, Tat $^{-}+$DOX, and Tat ${ }^{+}+$DOX $)$, four mice were used $(N=4)$ and $\geq 40$ cells were examined per mouse.

\section{Results}

\section{Oligodendrocyte morphology in Tat transgenic mice}

Fibrous astrocytes and OLs, the major cell types with cell bodies in the corpus callosum and anterior commissure, can be easily distinguished from each other in Golgi-Kopsch-impregnated sections by their distinct morphologies. Significantly more OLs with abnormal morphology, including stunted or swollen pro- cesses, large (several micrometers in diameter), club-like cytoplasmic endings, and aberrant cell bodies were noted in Tat ${ }^{+}$ mice when compared with their Tat ${ }^{-}$siblings with/without DOX (Fig. 1).

\section{Ultrastructure of $\mathrm{Tat}^{+}$mice}

We next asked whether Tat induction by DOX caused any injury at the subcellular level in the transgenic mice. EM revealed that many OLs in $\mathrm{Tat}^{+}$mice had a seemingly normal morphology and subcellular structure after 3 month DOX induction (Fig. $2 A$ ), yet a subpopulation showed very clear deficits. Enlarged periaxonal collars with dark cytoplasm were relatively common, potentially indicating accumulation of periaxonal fluid due to a deficit in exuding ion/fluid in OLs (Byun and Delpire, 2007; Fig. 2 B, C,E). Myelin splitting was also common and associated with both normal-appearing axons (Fig. $2 C, D, M-P$ ) and with axons exhibiting increased axoplasmic density (Fig. 2E). Abnormal membranous structures and membrane inclusions with apparent periodicity were often observed (Fig. $2 D-F, H$ ), indicating potential deficits in OL membrane turnover. Hypomyelinated axons (Fig. 2D,N) and myelin membranes without an associated axon (Fig. $2 J, L$ ) were also noted.

Tat expression leads to downregulated myelin proteins in vivo

A deficiency in MAG, which mediates axon-glial contact, has been reported to cause enlarged periaxonal collars (Trapp et al., 1984; Montag et al., 1994); decreased levels of MBP are often 
found in transgenic mice with myelin defects (Popko et al., 1987; Imgrund et al., 2009). We thus examined the expression level of MAG and MBP in Tat transgenic mice. Western blots of lysates from striatum showed that Tat $^{+}$mice exhibit significantly decreased levels of MAG and MBP when compared with their Tat ${ }^{-}$littermates after 3 months of DOX induction (Fig. 3).

\section{Characterization of OL cultures}

We used dissociated murine OL cultures to study whether the abnormalities of OLs and myelin in vivo were a direct effect of Tat or an indirect effect of Tat-induced inflammation. The percentage of cells expressing specific neural and glial cell markers was examined in cultures at 2-10 $\mathrm{d}$ after enrichment. Identification of OLs was made by immunostaining with the $\mathrm{O} 4$ antibody, which primarily detects the sulfated galactolipid sulfatide. In the CNS, sulfatide is expressed only by OLs; it is synthesized by immature, proliferating OLs and its expression is maintained in mature cells. As shown in Table $1,<5 \%$ of cells are positive for cell markers other than $\mathrm{O} 4$ in day 2 and 5 OL cultures. This ratio increases to $7-10 \%$ at day 7 and 10 . Hence, even after $10 \mathrm{~d}$ culture, $\geq 90 \%$ of cells in our culture are OLs. The majority of cells that are not $\mathrm{O}^{+}$are $\mathrm{GFAP}^{+}$astrocytes (Table 1).

\section{Dose-dependent effect of Tat on} viability of immature, but not mature, OLs in vitro

Day 2 and 7 OL cultures were treated with Tat or vehicle, and imaged hourly for 72 h. At day 2, almost all OLs showed an immature phenotype, with multiple fine processes extending from relatively condensed, ovoid cell bodies. In addition, there were no myelin-like membranes extended from processes (Fig. 4A,B). Over time, vehicle-treated cells showed signs of differentiation. The cell body became much larger with increased cytoplasmic area (Fig. 4A). The maturing OLs developed multiple, thick, primary processes from which emanated an extensive network of thinner processes with large, myelin-like membrane expansions that also were $\mathrm{O}^{+}{ }^{+}$. Compared with controls, the viability of immature OLs was significantly decreased in a dose-dependent manner after treatment with HIV-1 Tat (Fig. 4B,D-G). In addition, OLs surviving after $72 \mathrm{~h}$ lacked the extensive network of branching processes and myelin-like membrane extensions that are typical for healthy OLs at this age (Fig. 4A). A live/dead assay confirmed that OLs treated with Tat for 24-72 h exhibited significantly more EthD-1 staining and less calcein-AM staining than OLs in vehicle-treated

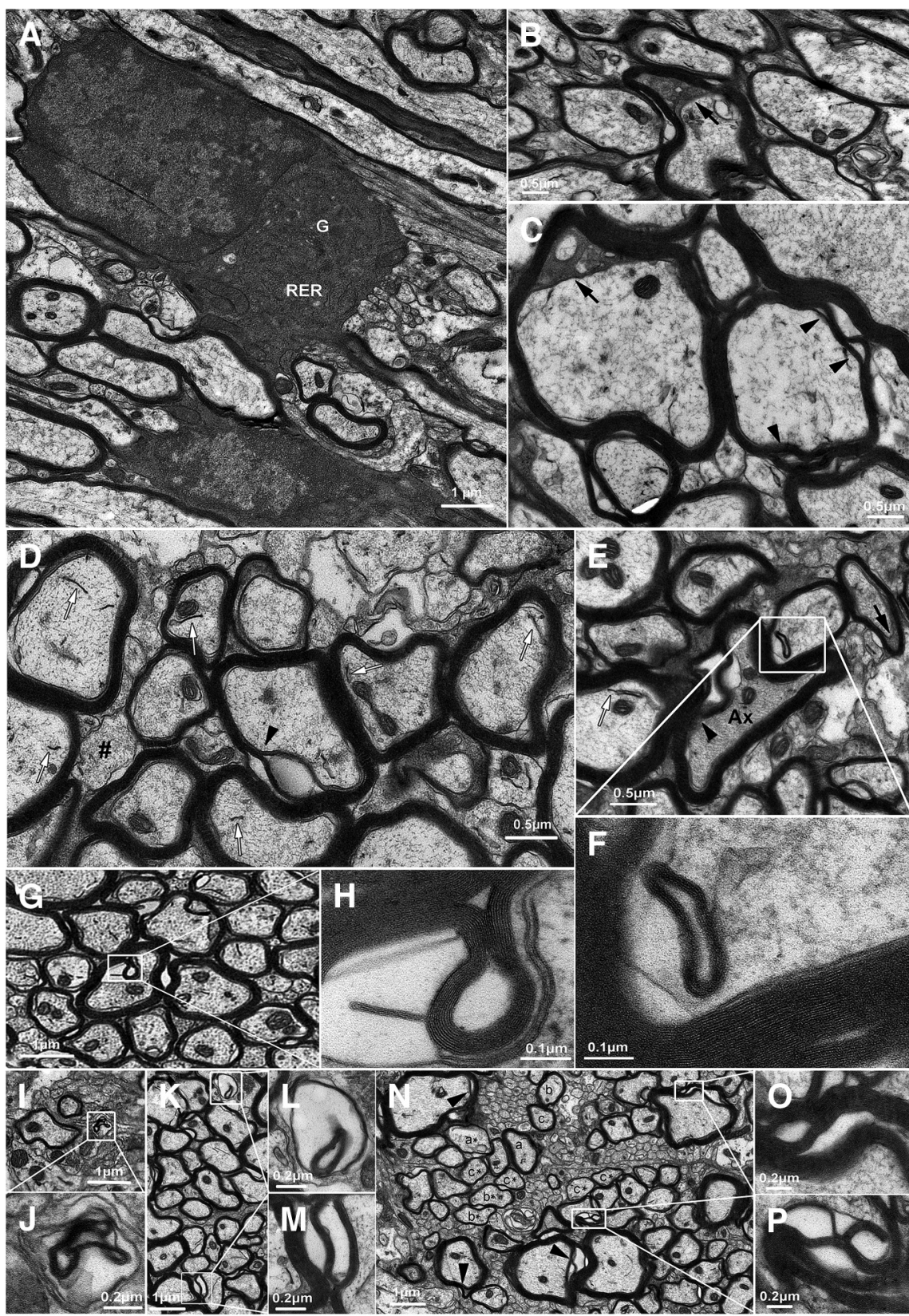

Figure 2. Ultrastructural examination of caudate-putamen in Tat ${ }^{+}$mice. $A$, Even after 3 months of continuous Tat expression, most OLs show a normal phenotype and subcellular structure (G, Golgi apparatus; RER, rough endoplasmic reticulum). $\boldsymbol{B}-\boldsymbol{P}$, Despite this observation, multiple abnormal structures were commonly observed and documented in a subset of Tat-exposed $0 \mathrm{LS}$. These include (1) enlarged periaxonal collars containing dark cytoplasm ( $\boldsymbol{B}, \boldsymbol{C}, \boldsymbol{E}$, black arrows), possibly due to accumulation of periaxonal fluid; (2) myelin splitting, suggesting a potential deficit of myelin compaction, found both with normal-appearing axons ( $\boldsymbol{M}, \boldsymbol{O}, \boldsymbol{P} ; \boldsymbol{C}, \boldsymbol{D}, \boldsymbol{N}$, arrowheads) and with axons exhibiting abnormally dense cytoplasm ( $\boldsymbol{E}$, arrowhead); (3) abnormal membranous structures $(\boldsymbol{D}, \boldsymbol{E}$, white arrows) and myelin-like membrane inclusions with obvious periodicity $(\boldsymbol{F}, \boldsymbol{H})$, indicating potential deficits in $\mathrm{OL}$ membrane turnover; (4) hypomyelination, as indicated by axons of similar calibers in the same region invested with myelin sheaths of different thickness ( $\boldsymbol{N}$, compare axon groups a- $\boldsymbol{c} v \mathrm{a} \mathrm{a}^{*}, \mathrm{~b}^{*}, \mathrm{C}^{*}$, respectively; also, in $\boldsymbol{D}$, note the axon marked with \#, which is unmyelinated, while neighboring axons with similar diameters have normal compact myelin); and (5) axons with abnormally dense cytoplasm $(\boldsymbol{E}, \mathrm{Ax})$ and myelin membrane in the absence of axon $(\boldsymbol{J}, \boldsymbol{L})$.

groups (Fig. $4 F, G$ ). On the other hand, Tat treatment had no effect on the viability of mature OLs (day 7; Fig. 4C,D).

Myelin-like membranes are reduced by Tat exposure

Since Tat did not reduce the viability of mature OLs, we examined whether it might affect their ability to form myelin-like membranes. Differentiating OLs in vitro produce characteristic 


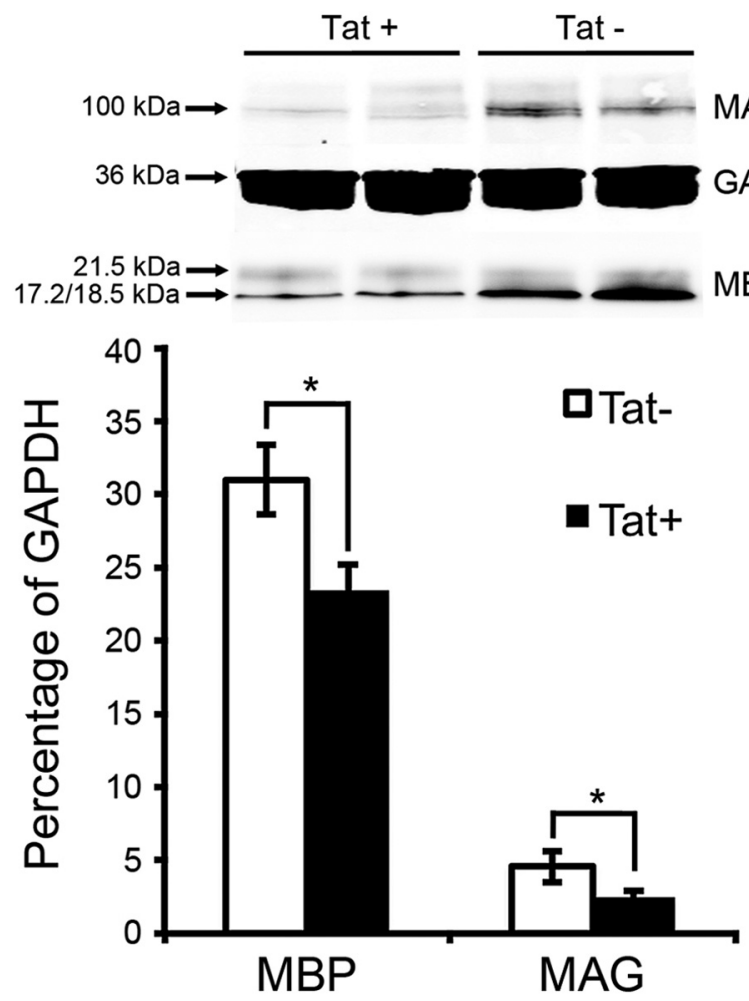

Figure 3. In vivo Tat expression leads to decreased MBP and MAG. Western blot analysis of tissue lysate from transgenic mice after 3 month Tat induction showed decreased levels of both MBP and MAG. Protein expression was normalized to glyceraldehyde 3-phosphate dehydrogenase (GAPDH; $n=4$; values are mean \pm SEM; ${ }^{*} p<0.05, t$ test).

Table 1. Percentage of cells expressing neuron/glial-specific markers at various times in vitro

\begin{tabular}{lllll}
\hline & 04+ & GFAP + & MAP2 + & lba + \\
\hline Day 2 ( $n=4,372$ cells) & $98.76 \pm 0.73 \%$ & $1.00 \pm 0.58 \%$ & $0 \%$ & $0.24 \pm 0.24 \%$ \\
Day 5 $(n=4,413$ cells) & $96.35 \pm 0.49 \%$ & $3.15 \pm 0.62 \%$ & $0 \%$ & $0.50 \pm 0.29 \%$ \\
Day 7 ( $n=4,396$ cells) & $93.18 \pm 0.15 \%$ & $5.35 \pm 0.61 \%$ & $0.25 \pm 0.25 \%$ & $1.22 \pm 0.46 \%$ \\
Day 10 ( $n=4,383$ cells) & $90.60 \pm 0.39 \%$ & $7.31 \pm 0.37 \%$ & $0 \%$ & $2.10 \pm 0.44 \%$ \\
\hline
\end{tabular}

$n$, Number of individual cultures; lba, ionized calcium-binding adaptor molecule 1.

membranes that are thought to be analogous to myelin membranes in the brain, and which contain all major lipids and proteins found in myelin within the CNS (Dubois-Dalcq et al., 1986; Knapp et al., 1987; Waggener et al., 2013). OL cultures at day 7 were labeled with CM-DiI before being treated with vehicle or Tat. Randomly selected cells with the morphology of maturing OLs were followed using a computer-controlled stage for $48 \mathrm{~h}$; phase contrast and fluorescent images were taken at 0,24 , and $48 \mathrm{~h}$. Calcein-AM was added to the cultures at the end of experiment to verify cell viability (Fig. $5 A$ ). Membrane area per OL, as indicated by CM-DiI labeling, was calculated using IPLab software as previously published (Dennis et al., 2008). In vehicletreated cultures, individual OLs showed a $\sim 30 \%$ increase of membrane area at $24 \mathrm{~h}$, suggesting new membrane production along with cell growth. This increased membrane size was maintained at $48 \mathrm{~h}$ (Fig. $5 B$ ). Tat $(1 \mathrm{nM})$ did not have a significant effect on OL membrane area. However, adding 10 or $100 \mathrm{~nm}$ Tat to the medium significantly decreased OL membrane area at $24 \mathrm{~h}$ $(\sim 75 \%$ of $0 \mathrm{~h})$, and this decreased membrane size was maintained at $48 \mathrm{~h}$ (Fig. 5B).
Tat induces $\mathrm{Ca}^{2+}$ influx and CaMKII $\beta$ activation in both mature and immature OLs in vitro

Since Tat has been reported to destabilize $\mathrm{Ca}^{2+}$ signaling in neurons (Kim et al., 2008; Perry et al., 2010), astroglia (El-Hage et al., 2005), and microglia (Sheng et al., 2000; Lokensgard et al., 2001), we hypothesized that the above-observed effects of Tat on OLs were mediated by changes in OL $\left[\mathrm{Ca}^{2+}\right]_{\mathrm{i}}$. To test this hypothesis, we first investigated whether Tat induces $\mathrm{OL}\left[\mathrm{Ca}^{2+}\right]_{\mathrm{i}}$ alterations. Figure 6 shows that Tat caused an increase in $\left[\mathrm{Ca}^{2+}\right]_{\mathrm{i}}$ in both day 2 and 7 OLs in a dose-dependent manner. The Tat-induced $\mathrm{Ca}^{2+}$ influx seems to start from distant regions of processes upon Tat addition to the medium (Fig. $6 B, D$ ). When challenged with 100 $\mathrm{nM}$ Tat, $\left[\mathrm{Ca}^{2+}\right]_{\mathrm{i}}$ levels rose to $\sim 150 \mathrm{nM}$ in day 2 OLs and $\sim 230 \mathrm{nM}$ in day 7 OLs, and these increased $\left[\mathrm{Ca}^{2+}\right]_{\mathrm{i}}$ levels were maintained during a $20 \mathrm{~min}$ experimental period (Fig. 6B,D-F). The Tatinduced $\left[\mathrm{Ca}^{2+}\right]_{\mathrm{i}}$ increase was dose dependent; with a lower Tat (1 $\mathrm{nM}$ ) exposure, $\left[\mathrm{Ca}^{2+}\right]_{\mathrm{i}}$ returned to control level after $5 \mathrm{~min}$ (Fig. $6 E, F$, cyan line). Furthermore, the Tat-induced $\left[\mathrm{Ca}^{2+}\right]_{\mathrm{i}}$ increase was completely abolished in $\mathrm{Ca}^{2+}$-free medium (Fig. $6 E$, F, blue line) and greatly attenuated when Tat was heat-inactivated (Fig. $6 E, F$, black line).

CaMKII $\beta$ is a molecule central to OL intracellular $\mathrm{Ca}^{2+}$ signaling pathways (Derkach et al., 1999; Bayer and Schulman, 2001; Hudmon and Schulman, 2002) and has been reported to be important in maturation and myelination (Waggener et al., 2013). We investigated whether CaMKII $\beta$ was activated as a consequence of the Tat-induced $\left[\mathrm{Ca}^{2+}\right]_{\mathrm{i}}$ increase. Both immature and mature OLs exposed to $100 \mathrm{~nm}$ Tat for $30 \mathrm{~min}$ showed significantly increased levels of CaMKII $\beta$ Thr-287 autophosphorylation, suggesting increased CaMKII $\beta$ activation (Fig. 7). In either immature or mature OLs, the expression level of total CaMKII $\beta$ was not affected by Tat treatment (data not shown).

Blocking iGluRs attenuates the Tat-induced $\left[\mathrm{Ca}^{2+}\right]_{\mathrm{i}}$ increases Interactions between Tat and iGluRs lead to iGluR activation and $\mathrm{Ca}^{2+}$ influx, which have been reported extensively in neurons (Haughey et al., 2001; Kim et al., 2008). We therefore examined whether the Tat-induced $\mathrm{Ca}^{2+}$ influx in OLs is also mediated by iGluRs. Since iGluR expression and subunit composition is developmentally regulated and highly heterogeneous (Gallo and Ghiani, 2000; Itoh et al., 2002; Cavaliere et al., 2012) in OLs, we first verified the expression of functional iGluRs on our cultured OLs. In immature, day 2 OLs, NMDA at both 50 and $300 \mu \mathrm{M}$ induced a minimum $\mathrm{Ca}^{2+}$ response (Fig. 8A, cyan and blue lines), while either 50 or $300 \mu \mathrm{M}$ AMPA induced a significant $\mathrm{Ca}^{2+}$ influx lasting $>20$ min (Fig. $8 A$, yellow and brown lines). These results are consistent with the fact that the majority of the iGluRs expressed on immature OL somas are AMPA/KARs (Gallo and Ghiani, 2000; Itoh et al., 2002). In mature OLs, $50 \mu \mathrm{M}$ NMDA invoked a small $\mathrm{Ca}^{2+}$ response $(\sim 60 \mathrm{nM})$ that was significantly above control levels ( $\sim 40 \mathrm{nM}$; Fig. $6 B$, cyan line vs white line). A higher NMDA exposure $(300 \mu \mathrm{M})$ elicited a sharp increase of $\left[\mathrm{Ca}^{2+}\right]_{\mathrm{i}}$ to a level similar to that induced by Tat (Fig. $8 B$, blue line, vs Fig. $6 F$, red line). This high $\left[\mathrm{Ca}^{2+}\right]_{\mathrm{i}}$ level came down to $\sim 60 \mathrm{~nm}$ within $10 \mathrm{~min}$, but remained significantly higher than in vehicle-treated OLs. The AMPA responses of mature OLs were somewhat different. AMPA $(50 \mu \mathrm{M})$ caused a moderate $\left[\mathrm{Ca}^{2+}\right]_{\mathrm{i}}$ increase in mature OLs that recovered within $10 \mathrm{~min}$ (Fig. $8 \mathrm{~B}$, yellow line $)$. AMPA $(300 \mu \mathrm{M})$ induced an initial $\left[\mathrm{Ca}^{2+}\right]_{\mathrm{i}}$ increase to $\sim 110 \mathrm{nM}$, which then rose consistently over the $20 \mathrm{~min}$ experimental period (Fig. $8 B$, brown line).

We next examined whether blocking iGluRs affected Tatinduced $\left[\mathrm{Ca}^{2+}\right]_{\mathrm{i}}$ changes in OLs. In immature OLs, the $\left[\mathrm{Ca}^{2+}\right]_{\mathrm{i}}$ 



Figure 4. Survival of Tat-treated $0 \mathrm{LS}$. $A-C$, Sample images of $0 \mathrm{~L}$ cultures treated with vehicle or Tat (100 $\mathrm{nm})$ after $0,24,48$, and $72 \mathrm{~h} . \boldsymbol{A}$, Immature $0 \mathrm{Ls}$ treated with vehicle grow normally and differentiate over the $72 \mathrm{~h}$ period. At the end of $72 \mathrm{~h}$, cells have complex process networks with myelin-like membranes (Scale bar, $100 \mu \mathrm{m}$ ). $\boldsymbol{B}$, Immature 0Ls treated with $100 \mathrm{~nm}$ Tat. Both $0 \mathrm{Ls}$ in the field were healthy at $0 \mathrm{~h}$. One $0 \mathrm{~L}$ was dead after $72 \mathrm{~h}$ (white arrow). Although the other $0 \mathrm{~L} \mathrm{survived,} \mathrm{its} \mathrm{process} \mathrm{network} \mathrm{was} \mathrm{greatly} \mathrm{reduced.} \mathrm{An} \mathrm{astrocyte} \mathrm{at} \mathrm{the} \mathrm{lower} \mathrm{right} \mathrm{corner} \mathrm{migrated} \mathrm{out}$ of the field by $24 \mathrm{~h}$. C, A mature $0 \mathrm{~L}$ treated with $100 \mathrm{~nm}$ Tat appeared healthy and still maintained a complex process network after $72 \mathrm{~h}$, even though it underwent extensive process reorganization. The double arrow marks a major process that was retracted. $\boldsymbol{D}, 0 \mathrm{~L}$ vulnerability to Tat was dependent on differentiation. Almost all mature $0 \mathrm{Ls}(>95 \%)$ survived for the $72 \mathrm{~h}$ experimental period, whether they were treated with vehicle or $100 \mathrm{~nm}$ Tat. In contrast, survival of immature $0 \mathrm{Ls}$ was significantly reduced by $100 \mathrm{~nm}$ Tat, even at $24 \mathrm{~h}$. ${ }^{*} p<0.05$ vs immature $0 \mathrm{~L}$ controls; 1 -way ANOVA followed by post hoc Bonferroni's test; $n=4$ individual experiments; $\geq 25$ cells were counted for each $n$ ). $\boldsymbol{E}$, Concentration-dependent effect of Tat on immature $0 \mathrm{~L} \mathrm{survival.} \mathrm{Immature} 0 \mathrm{Ls}$ at day 2 were treated with 1, 10, and $100 \mathrm{~nm}$ Tat for 24,48 , and $72 \mathrm{~h}$. Tat ( $1 \mathrm{nM}$ ) shows no obvious effect on $0 \mathrm{~L}$ survival, while $10 \mathrm{~nm}$ Tat reduces survival by $10-15 \%$ when compared with controls at 24 , 48 , and $72 \mathrm{~h}$. The cytotoxic effect of $100 \mathrm{~nm}$ Tat is even more significant ( $22-35 \%$ reduction in survival; ${ }^{*} p<0.05$ vs control; ${ }^{*} p<0.05$ vs 10 nm Tat group; 2 -way ANOVA followed by post hoc Bonferroni's test; $n=4$ individual experiments; $>40$ cells were counted for each $n$ ). $F, G$, The live- dead assay shows that $100 \mathrm{~nm}$ Tat significantly increased immature $0 \mathrm{~L}$ death at 24,48 , and $72 \mathrm{~h}$. F, Corresponding phase and fluorescent images of calcein-AM-labeled (live cells, green) and EthD-1-labeled (dead cells, red) day 2 immature $0 \mathrm{Ls}$ treated with vehicle or $100 \mathrm{~nm}$ Tat for $72 \mathrm{~h}$. The majority of cells in the cultures appeared to shift from green to red with Tat treatment. $\mathbf{G}$, At all time points, $100 \mathrm{~nm}$ Tat significantly increased the (Figure legend continues.) 

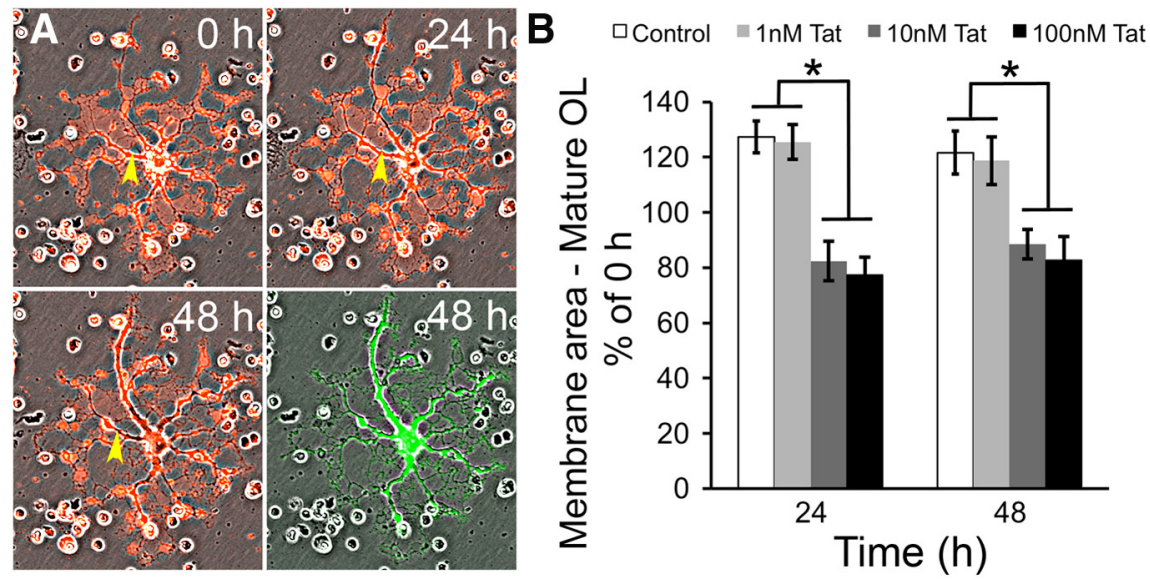

Figure 5. Tat reduces myelin-like membranes of mature $0 \mathrm{LS}$. A, Sample images showing changes in mature $0 \mathrm{~L}$ membrane area over $48 \mathrm{~h}$. Cells were labeled with $2 \mu \mathrm{g} / \mathrm{ml} \mathrm{CM}$-Dil $1 \mathrm{~d}$ before Tat treatment. Phase contrast and fluorescent images of the same cell were taken at 0,24 , and $48 \mathrm{~h}$. Phase and fluorescent images were merged to better visualize the myelin-like membrane structures. At the end of the experimental period, cells were labeled with calcein-AM to verify viability (green fluorescence). The yellow arrowhead indicates an area with an obvious reduction in the area of the cellular processes (loss of red fluorescence) over time. $\boldsymbol{B}$, Quantification of the change in membrane area in vehicle and Tat-treated OLs. At both 24 and $48 \mathrm{~h}$, vehicle-treated OLs showed $\sim 25 \%$ growth of membrane area. Tat $(1 \mathrm{nM})$ did not have any significant effect on the membrane area when compared with controls. However, 10 or $100 \mathrm{~nm}$ Tat-treated $0 \mathrm{Ls}$ at 24 and $48 \mathrm{~h}$ exhibited $\sim 20 \%$ reductions in membrane area compared with $0 \mathrm{~h}$ ( $p<0.05$, 2-way ANOVA followed by post hoc Bonferroni's test; $n=4$ individual experiments; $\geq 25$ cells were counted for each $n$ ).
The Tat-induced OL $\left[\mathrm{Ca}^{2+}\right]_{\mathrm{i}}$ increase was abolished in $\mathrm{Ca}^{2+}$-free medium (Fig. $6 E, F)$. To test whether the initial $\mathrm{Ca}^{2+}$ influx triggers $\mathrm{Ca}^{2+}$-induced $\mathrm{Ca}^{2+}$ release from internal stores, immature/mature OLs were treated with $10 \mu \mathrm{M}$ dantrolene for $20 \mathrm{~min}$ before addition of Tat. This had no effect on Tat-induced $\left[\mathrm{Ca}^{2+}\right]_{\mathrm{i}}$ change in OLs. OLs express abundant $\alpha_{\mathrm{v}} \beta_{3}$ integrin (Fig. 9B), which has been reported to interact with Tat (Urbinati et al., 2005b, 2012). However, blocking integrin with the RGDS inhibitor peptide had no effect on Tat-induced $\left[\mathrm{Ca}^{2+}\right]_{\mathrm{i}}$ increases in immature or mature OLs (Fig. 9A). Similarly, the L-type voltage-gated calcium channel blocker nimodipine $(10 \mu \mathrm{M})$, CCR2 receptor inhibitor RS102895 (10 $\mu \mathrm{M})$, CCR3 receptor inhibitor SB328437 $(10 \mu \mathrm{M})$, and sodium-dependent glutamate transporter inhibitor DL-TBOA $(100 \mu \mathrm{M})$ all had no effect on Tat-induced $\left[\mathrm{Ca}^{2+}\right]_{i}$ changes in either immature or mature OLs (Fig. 9A). increase induced by $10 \mathrm{nM}$ Tat was blocked by both MK801 and CNQX (Fig. 8C,E, yellow line), but $\left[\mathrm{Ca}^{2+}\right]_{\mathrm{i}}$ increases induced by $100 \mathrm{~nm}$ Tat were only reduced to $\sim 100 \mathrm{~nm}$ (Fig. $8 C, E$, brown line). MK801 and CNQX additively inhibited the effect of $100 \mathrm{nM}$ Tat, but could not block the $\left[\mathrm{Ca}^{2+}\right]_{\mathrm{i}}$ increase (Fig. $8 G$, brown line). The response in mature OLs was different. With $10 \mathrm{~nm}$ Tat, the initial $\left[\mathrm{Ca}^{2+}\right]_{\mathrm{i}}$ level was significantly attenuated by MK801 or CNQX, and the $\left[\mathrm{Ca}^{2+}\right]_{\mathrm{i}}$ level gradually returned to control over 5 min (Fig. 8D,F, yellow line). When MK801 and CNQX were added together, the effect of $10 \mathrm{~nm}$ Tat was blocked (Fig. $8 \mathrm{H}$, yellow line). In contrast, only MK801 attenuated the initial $\left[\mathrm{Ca}^{2+}\right]_{\mathrm{i}}$ rise caused by $100 \mathrm{~nm}$ Tat, which was reduced to $\sim 90 \mathrm{nM}$ and maintained at this level over the 20 min experimental period. With CNQX, $\left[\mathrm{Ca}^{2+}\right]_{\mathrm{i}}$ levels were reduced only at later time points (Fig. $8 D, F$, brown line). MK801 and CNQX together had no additive effect on $100 \mathrm{~nm}$ Tat-induced $\left[\mathrm{Ca}^{2+}\right]_{\mathrm{i}}$ change in mature OLs (Fig. $8 H$, brown line). These results indicated that Tatinduced $\left[\mathrm{Ca}^{2+}\right]_{\mathrm{i}}$ changes in OLs were mediated by both NMDAR and AMPA/KAR activation. Further, since iGluR antagonists (20 $\mu \mathrm{M})$ did not block $\left[\mathrm{Ca}^{2+}\right]_{\mathrm{i}}$ changes induced by the higher Tat concentration $(100 \mathrm{~nm})$, Tat may activate iGluRs in a way that cannot be completely inhibited by MK801/CNQX, or Tat may interact with other molecules on the surface of OLs that mediate $\left[\mathrm{Ca}^{2+}\right]_{\mathrm{i}}$ change.

\section{Blocking alternative, non-iGluR targets has no effect on Tat-} induced increases in $\left[\mathrm{Ca}^{2+}\right]_{\mathrm{i}}$

Since Tat-induced $\left[\mathrm{Ca}^{2+}\right]_{\mathrm{i}}$ increases were not blocked by inhibiting iGluRs, we tested a series of alternative $\mathrm{Ca}^{2+}$ modulators.

\section{$\leftarrow$}

(Figure legend continued.) proportion of red pixels and reduced numbers of green pixels, indicating less $0 \mathrm{~L}$ survival with Tat and validating the visual observation in $\boldsymbol{F}\left({ }^{*} p<0.05\right.$ number of red pixels; Tat vs control of same time point; ${ }^{\#} p<0.05$, number of green pixels; Tat vs control of same time point; 1-way ANOVA followed by post hoc Bonferroni's test; $n=4$ individual experiments; 20 randomly selected images were analyzed for each $n$ ).

\section{CNQX and MK801 effects on OL survival and} membrane production

Since Tat-induced $\left[\mathrm{Ca}^{2+}\right]_{\mathrm{i}}$ changes were attenuated by MK801 and/or CNQX, we examined whether blocking iGluRs would also reverse Tat effects on immature OL survival. Both CNQX and MK801 $(20 \mu \mathrm{M})$ reversed the effect of Tat on OL viability at 24, 48 , and $72 \mathrm{~h}$. CNQX by itself had no effect on OL viability, while cells treated with MK801 alone had a significantly higher survival rate than controls (Fig. 10A). We next tested whether blocking iGluRs could also reverse the effect of Tat on the area of myelinlike membranes produced by mature OLs. Neither CNQX nor MK801 by themselves had any effect on the area of myelin-like membranes produced by mature OLs at either 24 or $48 \mathrm{~h}$. Exposure to $100 \mathrm{~nm}$ Tat significantly decreased the size of the membrane area by $>20 \%$ after $24 \mathrm{~h}$. This effect was reversed by MK801, but not by CNQX. Results at $48 \mathrm{~h}$ were similar (Fig. 10B).

\section{Discussion}

Our findings establish that HIV-1 Tat, through activation of iGluRs, increases $\left[\mathrm{Ca}^{2+}\right]_{\mathrm{i}}$ and CaMKII $\beta$ activation in OLs. In vivo, transgenic mice with inducible Tat expression had higher numbers of OLs with an abnormal phenotype in Golgiimpregnated cells, disturbances in myelin ultrastructure, and decreased myelin protein (MBP and MAG) expression. In highly purified murine OL cultures, the outcome of Tat exposure varied with the stage of differentiation. At Tat levels that reduced immature OL survival, mature OLs remained viable despite persistent elevations in $\left[\mathrm{Ca}^{2+}\right]_{\mathrm{i}}$, but had reduced myelin-like membrane areas.

\section{Effects of Tat in vivo}

Although cART suppresses CSF HIV RNA levels to below clinical detection limits (Staprans et al., 1999; Yilmaz et al., 2006), HAND still occurs in $\sim 60 \%$ of patients, suggesting that CNS injury can occur without viral replication. Tat may be an important mediator of HAND, as it can be produced in the ab- 


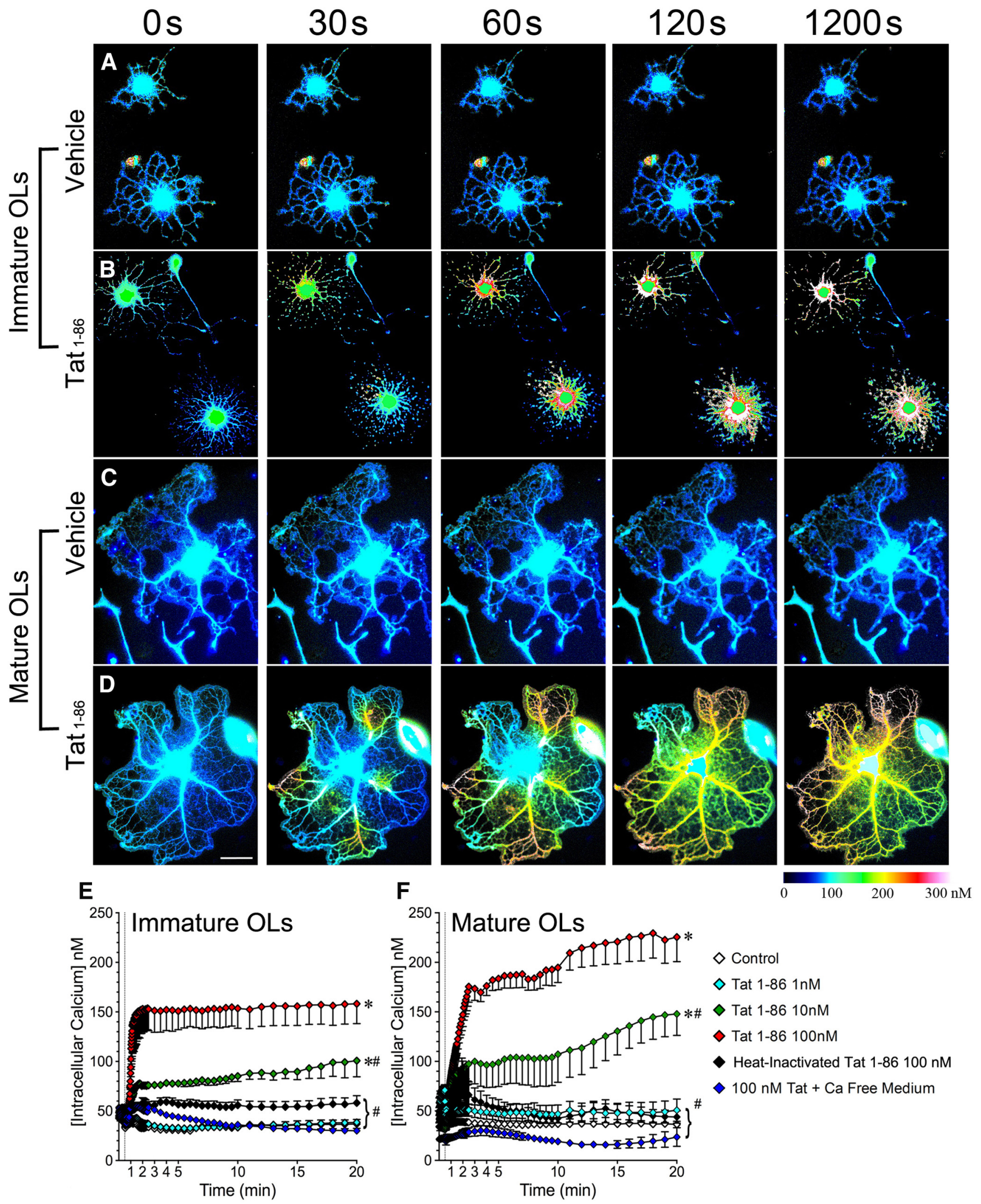

Figure 6. Tat induces $\mathrm{Ca}^{2+}$ influx in mature and immature $0 \mathrm{Ls} . \boldsymbol{A}-\boldsymbol{D}$, Sample images showing changes of intracellular $\mathrm{Ca}^{2+}$ concentration over a 20 min period in immature $(\boldsymbol{A}, \boldsymbol{B})$ and mature $(\boldsymbol{C}, \boldsymbol{D})$ OLs treated with vehicle $(\boldsymbol{A}, \boldsymbol{C})$ or $100 \mathrm{~nm}$ Tat $(\boldsymbol{B}, \boldsymbol{D})$. [ $\left[\mathrm{Ca}^{2+}\right]_{\mathrm{i}}$ was assessed by fura-2 AM 380/340 fluorescence ratio and displayed as pseudocolored images generated by Zeiss AxioVision 4.8 software. $\boldsymbol{E}, \boldsymbol{F}$, Tat induces dose-dependent $\left[\mathrm{Ca}^{2+}\right]_{\mathrm{i}}$ increases in both immature $(\boldsymbol{E})$ and mature $(\boldsymbol{F}) 0 \mathrm{Ls}$. This effect is completely abolished in $\mathrm{Ca}^{2+}$-free medium, and greatly attenuated by heat inactivation of Tat [vertical dashed line indicates the time point ( $30 \mathrm{~s}$ ) when treatment was added ${ }^{*} p<0.05$ vs control; ${ }^{*} p<0.05$, vs 100 nm Tat; 2-way ANOVA followed by post hoc Bonferroni's test; $n=4$ individual experiments; $\geq 7$ cells were counted for each $n$. Scale bar, $50 \mu \mathrm{m}]$. 

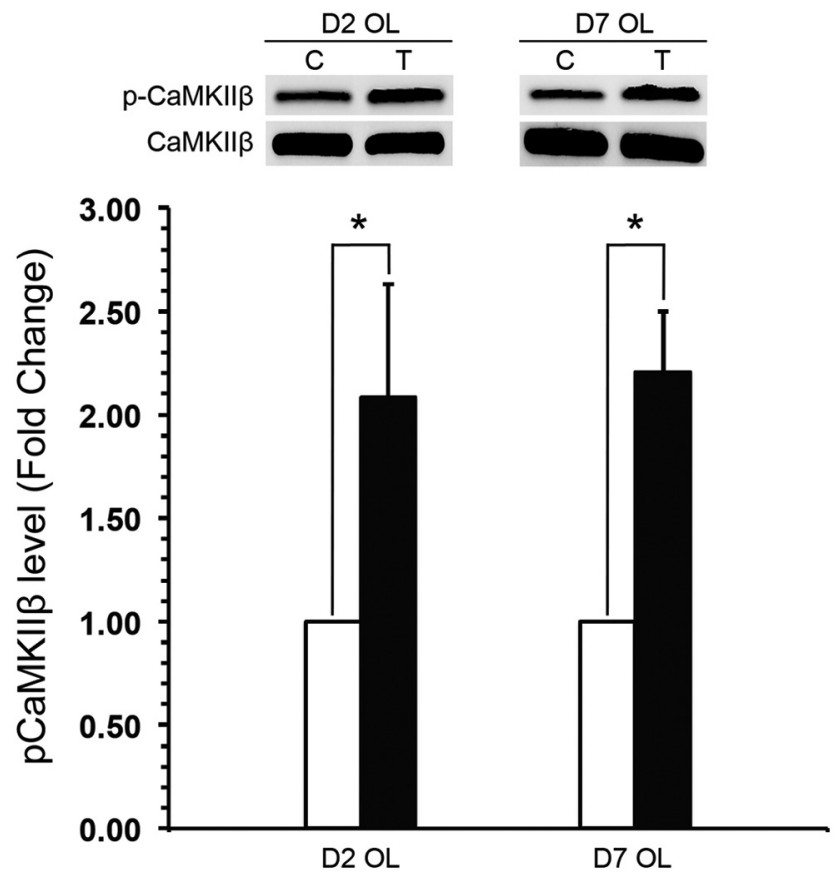

Figure 7. Tat induces CaMKII $\beta$ Thr-287 phosphorylation in mature and immature OLs. Western blot analysis showed that Tat increased the level of CaMKII $\beta$ Thr-287 phosphorylation in both immature and mature $0 \mathrm{Ls}$ by $30 \mathrm{~min}\left(n=6\right.$; values are mean $\pm \mathrm{SEM} ;{ }^{*} p<0.05, t$ test $)$.

sence of viral replication, and has been shown to be at high titers in the CSF of cART-controlled patients (Johnson et al., 2013). Multiple cellular abnormalities have been reported in Tat transgenic mice, including reactive astrogliosis and microgliosis (Bruce-Keller et al., 2008), elevated caspase-3 activation in OLs (Hauser et al., 2009), and synaptodendritic injury (Kim et al., 2003; Fitting et al., 2014), which coincides with deficits in behavior, including learning and memory (Carey et al., 2012; Fitting et al., 2013), and cognitive/motor impairments (Hahn et al., 2015). Most studies suggest Tat-induced inflammation as the predominant cause of CNS injury. However, controlled trials of cART with adjunctive "anti-inflammatory" agents do not show greater efficacy against HAND than cART alone (Tan and McArthur, 2012), suggesting neurotoxic effectors in addition to inflammation. Our in vivo studies showed that Tat caused myelin damage and OL injury, and we showed direct Tat toxicity to OLs using a highly purified culture system ( $>90 \%$ OLs) and Tat concentrations that reasonably approximate titers in HIV-infected brains (see Materials and Methods).

\section{Tat-induced $\left[\mathrm{Ca}^{2+}\right]_{\mathrm{i}}$ increases}

Tat disrupts $\mathrm{Ca}^{2+}$ homeostasis in astroglia (El-Hage et al., 2005, 2008b), microglia (Sheng et al., 2000; Lokensgard et al., 2001), macrophages (Contreras et al., 2005), and neurons (Haughey and Mattson, 2002; Zhu et al., 2009). We found that Tat induced a concentration-dependent $\left[\mathrm{Ca}^{2+}\right]_{\mathrm{i}}$ increase in both immature and mature OLs. The primary source of $\mathrm{Ca}^{2+}$ was extracellular, since the $\left[\mathrm{Ca}^{2+}\right]_{\mathrm{i}}$ increases were abolished in $\mathrm{Ca}^{2+}$-free medium. Transient $\left[\mathrm{Ca}^{2+}\right]_{\mathrm{i}}$ increases occurred at 1 $\mathrm{nm}$ Tat with more sustained $\left[\mathrm{Ca}^{2+}\right]_{\mathrm{i}}$ elevations at $10-100 \mathrm{~nm}$ Tat. Higher Tat concentrations ( $\geq 10 \mathrm{~nm}$ ) may elicit an initial $\left[\mathrm{Ca}^{2+}\right]_{\mathrm{i}}$ increase that depolarizes the membrane, leading to secondary $\mathrm{Ca}^{2+}$ influx via voltage-gated calcium channels. Such channels are expressed by OLs and activated by cation influx via glycine receptors and $\mathrm{Na}^{+}$-dependent transporters (Kirischuk et al., 1995; Belachew et al., 2000). Alternatively, the $\left[\mathrm{Ca}^{2+}\right]_{\mathrm{i}}$ increase induced by $1 \mathrm{~nm}$ Tat may be below the threshold required to activate $\mathrm{Ca}^{2+}$-induced $\mathrm{Ca}^{2+}$ release from internal $\mathrm{Ca}^{2+}$ stores. Neither the L-type voltage-gated calcium channel blocker nimodipine nor the ryanodine receptor inhibitor dantrolene affected Tat-induced $\left[\mathrm{Ca}^{2+}\right]_{\mathrm{i}}$ increases (Fig. 9A), indicating involvement of alternative molecular targets (see below). Notably, $1 \mathrm{~nm}$ Tat does not affect immature OL viability or mature OL membrane area. These results strongly suggest the existence of a $\left[\mathrm{Ca}^{2+}\right]_{i}$ threshold above which downstream signaling molecules involved in functional effects, such as CaMKII $\beta$, will be activated.

\section{iGluRs expression on OLs}

We found that stage of development was a significant determinant in the OL response to Tat, possibly due to developmentally regulated expression of iGluRs on OLs (Deng et al., 2003). In OL cultures, AMPA elicited a dose-dependent $\left[\mathrm{Ca}^{2+}\right]_{\mathrm{i}}$ increase in immature OLs, while even high NMDA concentrations elevated $\left[\mathrm{Ca}^{2+}\right]_{\mathrm{i}}$ minimally (Fig. $6 \mathrm{~A}$ ). Mature OLs responded to both AMPA and NMDA with prominent $\left[\mathrm{Ca}^{2+}\right]_{\mathrm{i}}$ increases. These results are consistent with earlier studies showing that NMDA-evoked currents were detected in precursor, immature, and mature OLs isolated from murine cerebellum and corpus callosum (Káradóttir et al., 2005; Salter and Fern, 2005). A more recent study by Alix and Fern (2009) also demonstrated the colocalization of NMDAR NR1 subunit and CNPase ${ }^{+}$oligodendroglial processes in postnatal day 10 rat optic nerve. At odds with these reports, De Biase et al. (2010) assessed gene expression in acutely purified/sorted CNS cells (Cahoy et al., 2008) and concluded that levels of NMDARs and AMPARs are high in $\mathrm{NG}^{+}{ }^{+} \mathrm{OL}$ progenitors, but decline markedly with maturation. Different receptor levels might reflect the effect of isolation procedures, although this has not been explored.

NMDARs on myelinating OLs in vivo were found clustered in processes and on myelin (Salter and Fern, 2005; Micu et al., 2006). Consistent with this localization, the $\left[\mathrm{Ca}^{2+}\right]_{\mathrm{i}}$ increases mediated by Tat-NMDAR interactions began at distal processes and traveled proximally (Fig. 6). De Biase et al. (2010) released caged glutamate by UV photolysis in a $100 \mu \mathrm{m}$ circle centered on the cell body, and only detected slight NMDA currents. Glutamate released in this way may be sequestered by neighboring cells before stimulating NMDARs on more distal OL processes. It is noteworthy that $\mathrm{Ca}^{2+}$ responses to AMPA in immature OLs are more homogeneous than in mature OLs, suggesting a higher variability of AMPAR expression or a greater diversity in the composition of AMPAR subunits with maturation, as seen in vivo (Matute et al., 2002; Williams et al., 2009).

\section{iGluRs mediate Tat-induced $\left[\mathrm{Ca}^{2+}\right]_{\mathrm{i}}$ increases}

It is not surprising that Tat interacts with NMDARs on OLs, since Tat-NMDAR interactions occur in neurons (King et al., 2006; Kim et al., 2008; Capone et al., 2013; Rumbaugh et al., 2013;). However, since NMDA minimally affected $\left[\mathrm{Ca}^{2+}\right]_{\mathrm{i}}$ in immature OLs, it was intriguing that Tat-induced $\left[\mathrm{Ca}^{2+}\right]_{\mathrm{i}}$ increases were attenuated by MK801. Tat and NMDA appear to interact differently with NMDARs, since Tat-NMDAR interactions cause persistent, rather than transient, $\left[\mathrm{Ca}^{2+}\right]_{\mathrm{i}}$ increases (Fig. 8; Fitting et al., 2014). CNQX also attenuated the 

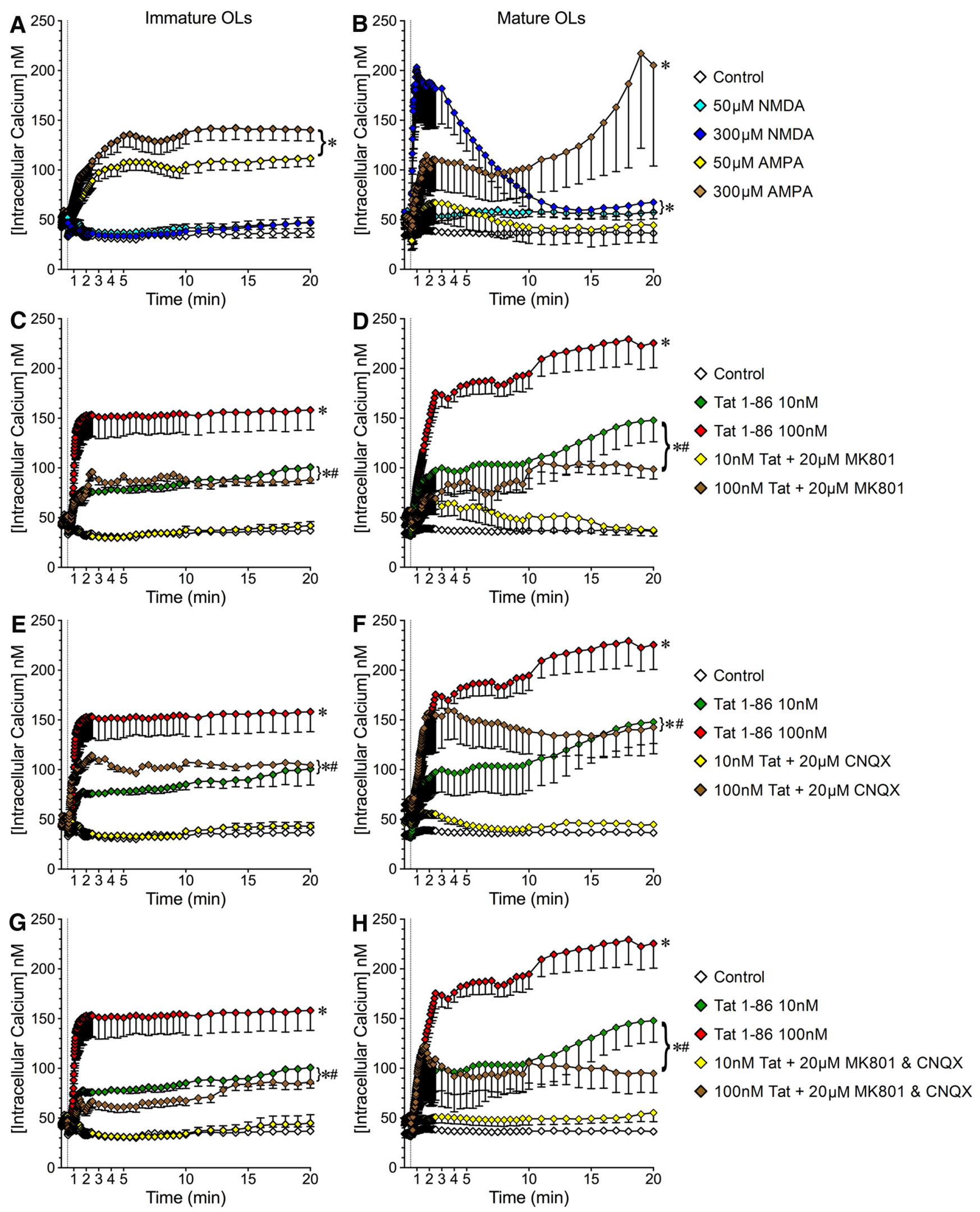

Figure 8. Tat-induced $\left[\mathrm{Ca}^{2+}\right]_{\mathrm{i}}$ increases in mature and immature $0 \mathrm{Ls}$ are partially reversed by iGluR antagonists. $A, B$, Expression of functional NMDARs and AMPARs on $0 \mathrm{Ls}$. $A$, In immature $0 \mathrm{LS}$, AMPA (at both 50 and $300 \mu \mathrm{m}$ ) causes $\left[\mathrm{Ca}^{2+}\right]_{\mathrm{i}}$ increases while NMDA responses are minimal. $\boldsymbol{B}$, In mature $0 \mathrm{Ls}$, NMDA leads to a dose-dependent $\left[\mathrm{Ca}^{2+}\right]_{\mathrm{i}}$ increase. AMPA elicits a $\left[\mathrm{Ca}^{2+}\right]_{\mathrm{i}}$ increase only at the higher $300 \mu \mathrm{m}$ concentration, and variability between cells is quite high. $\mathbf{C}-\boldsymbol{H}$, iGluR antagonists attenuate Tat-induced $\left[\mathrm{Ca}^{2+}\right]_{\mathrm{i}}$ increases in $0 \mathrm{Ls}$. C, E, G, In immature $0 \mathrm{LS}, \mathrm{MK} 801$ and/or CNQX blocks the $\left[\mathrm{Ca}^{2+}\right]_{\mathrm{i}}$ increase induced by $10 \mathrm{~nm}$ Tat but only partially inhibits the $\left[\mathrm{Ca}^{2+}\right]_{\mathrm{i}}$ increase elicited by $100 \mathrm{~nm} \mathrm{Tat.} \boldsymbol{D}, \boldsymbol{F}, \boldsymbol{H}$, In mature $0 \mathrm{Ls}$, the $10 \mathrm{~nm}$ Tat-induced $\left[\mathrm{Ca}^{2+}\right]_{\mathrm{i}}$ increase is similarly abolished by MK801 and/or CNQX. In contrast, the $\left[\mathrm{Ca}^{2+}\right]_{\mathrm{i}}$ increase induced by $100 \mathrm{~nm}$ Tat is only partially blocked by MK801 and/or CNQX ( ${ }^{*} p<0.05$ vs control; ${ }^{\#} p<0.05 \mathrm{vs} 100 \mathrm{~nm}$ Tat; 2 -way ANOVA followed by post hoc Bonferroni's test; $n=4$ individual experiments; $\geq 7$ cells were counted per treatment for each $n$ ). 

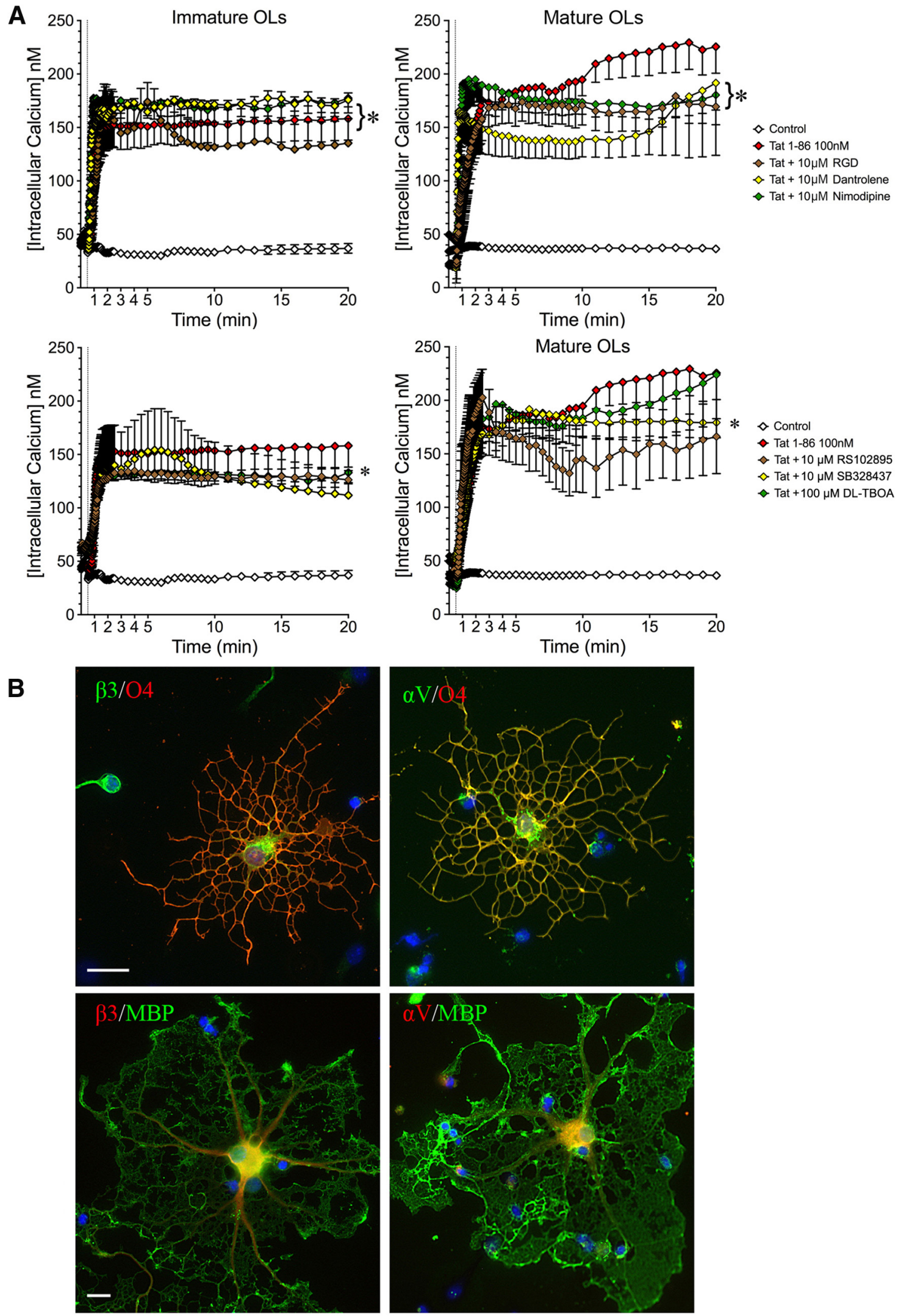

Figure 9. Blocking alternative, non-iGluR targets has no effect on Tat-induced increases in $\left[\mathrm{Ca}^{2+}\right]_{\mathrm{i}} \cdot \boldsymbol{A}$, Immature or mature OLs were exposed to nimodipine (L-type voltage-gated calcium channel inhibitor, $10 \mu \mathrm{M}$ ), dantrolene (ryanodine receptor inhibitor, $10 \mu \mathrm{M}$ ), DL-TBOA (sodium-dependent glutamate transporter inhibitor, $100 \mu \mathrm{m}$ ), RS102895 (CCR2 inhibitor, $10 \mu \mathrm{M}$ ), SB328437 (CCR3 inhibitor, $10 \mu \mathrm{M}$ ), or the RGDS peptide (integrin inhibitor, $10 \mu \mathrm{m}$ ) for $20 \mathrm{~min}$ before Tat treatment. None of these inhibitors affected Tat-induced $0 \mathrm{~L}\left[\mathrm{Ca}^{2+}\right]_{\mathrm{i}}$ increases $\left({ }^{*} p<0.05 \mathrm{vs}\right.$ control; 2-way ANOVA followed by post hoc Bonferroni's test; $n=3$ individual experiments; $\geq 7$ cells were counted for each $n$ ). B, Expression of $\alpha \mathrm{V}$ and $\beta 3$ integrin on $04+$ and MBP $+0 \mathrm{Ls}$ (scale bar, 50 $\mu \mathrm{m})$. 
effects of Tat on $\left[\mathrm{Ca}^{2+}\right]_{\mathrm{i}}$, which was unexpected since direct Tat-AMPA/KAR interactions have never been reported. In neurons, activation of cytoplasmic CaMKII recruits AMPARs from intracellular vesicles to cytoplasmic membranes, and increases the likelihood of channel opening by phosphorylating Ser-831 of AMPAR GluA1 subunits (Milstein and Nicoll, 2008; Derkach, 2011; Kristensen et al., 2011). We found that exposure to Tat leads to phosphorylation and activation of CaMKII $\beta$ in OLs (Fig. 7). Since their expression of the major cytoplasmic $\mathrm{Ca}^{2+}$ binding protein calbindin is extremely low compared with other CNS cells (Baimbridge et al., 1992; Zhang et al., 2014), we propose that Tat-NMDAR interactions lead to an initial $\mathrm{Ca}^{2+}$ influx that activates CaMKII $\beta$, which then recruits and phosphorylates AMPARs and raises $\left[\mathrm{Ca}^{2+}\right]_{\mathrm{i}}$ levels. Combined MK801 and CNQX had no additive effect, implicating additional, non-iGluR cellular components in $\mathrm{Ca}^{2+}$ responses to Tat. Blocking experiments preclude a role for integrins, chemokine receptors CCR3 and CCR2, sodium-dependent glutamate transporters, and ryanodine receptors in Tat-induced $\left[\mathrm{Ca}^{2+}\right]_{\mathrm{i}}$ increases (Fig. 9). Similar to neurons (Fitting et al., 2014), Tat-activated NMDARs might cause $\mathrm{Na}^{+}$influx, reversing $\mathrm{Na}^{+} / \mathrm{Ca}^{2+}$ exchange and destabilize mitochondrial inner membrane potential.

\section{Effects of Tat on OL viability and function}

$\mathrm{Ca}^{2+}$ influx via AMPA/KARs can activate various death pathways in OLs (Matute, 2011). AMPAR activation leads to caspase-8 recruitment and Bid truncation, while KAR activation has been linked to caspase-3 and caspase-9 activation (Sanchez-Gomez et al., 2003; Matute et al., 2006). We found that CNQX completely reversed Tatinduced death of immature OLs, implicating activation of AMPA/ KAR-mediated death pathways. Surprisingly, MK801 had a similar effect, suggesting a requirement for both NMDARs and AMPA/ KARs. This further implicates NMDAR-mediated AMPA/KAR activation. Interestingly, MK801 increased baseline survival of immature OLs, suggesting that some glutamate is released from OLs injured during the culture process.

Mature OLs remained viable when exposed to Tat, even when $\left[\mathrm{Ca}^{2+}\right]_{\mathrm{i}}$ was elevated to a level that resulted in the death of immature OLs, consistent with a previous finding that $\mathrm{Ca}^{2+}$-dependent excitotoxicity decreases with OL maturation (McDonald et al., 1998; Kavanaugh et al., 2000; Itoh et al., 2002; Deng et al., 2003). Rumbaugh et al. (2013) have proposed that the peptide Tat ${ }_{31-61}$ directly binds the NR1 subunit resulting in NMDAR activation. In vivo, NMDARs are mainly clustered on cytoplasmic processes, including the myelin sheath, and their activation causes process degeneration and myelin injury (Micu et al., 2006). Consistent with this subcel- lular distribution of NMDARs, our experiments showed that Tat-induced $\left[\mathrm{Ca}^{2+}\right]_{\mathrm{i}}$ increases in mature OLs originate at the distal processes and/or the peripheral edge of the myelin-like membranes (Fig. 6D). Importantly, the resultant reduction in myelin-like membranes can be reversed by MK801, but not CNQX (Fig. 10), suggesting the membrane retraction/OL injury is mediated by a common mechanism involving NMDAR activation and $\mathrm{Ca}^{2+}$ influx. It is possible that $\mathrm{Ca}^{2+}$ influx due to Tat-NMDAR interactions will generate a highly localized increase in $\left[\mathrm{Ca}^{2+}\right]_{\mathrm{i}}$ within distal processes/myelin membranes that leads to local CaMKII $\beta$ activation (Fig. 7). Waggener et al. (2013) showed that CaMKII $\beta$ regulates OL maturation and CNS myelination by stabilizing the actin cytoskeleton. Our findings suggest that CaMKII $\beta$ activation by Tat may also underlie some myelin damage with HIV infection.

Myelin damage and WM injury in HIV patients have been attributed to blood-brain barrier damage and to secondary effects mediated by inflammatory responses. Given the enriched nature of OL cultures in our studies, and their rapid increases in $\left[\mathrm{Ca}^{2+}\right]_{\mathrm{i}}$ upon Tat exposure, we propose that immature and mature OLs can be direct targets of Tat. Since iGluR antagonists can partially or fully reverse the detrimental effects of Tat, glutamate receptors could be a potential therapeutic target for WM damage in HIV patients. 


\section{References}

Alix JJ, Fern R (2009) Glutamate receptor-mediated ischemic injury of premyelinated central axons. Ann Neurol 66:682-693. CrossRef Medline

Baimbridge KG, Celio MR, Rogers JH (1992) Calcium-binding proteins in the nervous system. Trends Neurosci 15:303-308. CrossRef Medline

Bayer KU, Schulman H (2001) Regulation of signal transduction by protein targeting: the case for CaMKII. Biochem Biophys Res Commun 289:917923. CrossRef Medline

Belachew S, Malgrange B, Rigo JM, Rogister B, Leprince P, Hans G, Nguyen L, Moonen G (2000) Glycine triggers an intracellular calcium influx in oligodendrocyte progenitor cells which is mediated by the activation of both the ionotropic glycine receptor and $\mathrm{Na}+$-dependent transporters. Eur J Neurosci 12:1924-1930. CrossRef Medline

Bruce-Keller AJ, Turchan-Cholewo J, Smart EJ, Geurin T, Chauhan A, Reid R, Xu R, Nath A, Knapp PE, Hauser KF (2008) Morphine causes rapid increases in glial activation and neuronal injury in the striatum of inducible HIV-1 Tat transgenic mice. Glia 56:1414-1427. CrossRef Medline

Byun N, Delpire E (2007) Axonal and periaxonal swelling precede peripheral neurodegeneration in KCC3 knockout mice. Neurobiol Dis 28: 39-51. CrossRef Medline

Cahoy JD, Emery B, Kaushal A, Foo LC, Zamanian JL, Christopherson KS, Xing Y, Lubischer JL, Krieg PA, Krupenko SA, Thompson WJ, Barres BA (2008) A transcriptome database for astrocytes, neurons, and oligodendrocytes: a new resource for understanding brain development and function. J Neurosci 28:264-278. CrossRef Medline

Capone C, Cervelli M, Angelucci E, Colasanti M, Macone A, Mariottini P, Persichini T (2013) A role for spermine oxidase as a mediator of reactive oxygen species production in HIV-Tat-induced neuronal toxicity. Free Radic Biol Med 63:99-107. CrossRef Medline

Carey AN, Sypek EI, Singh HD, Kaufman MJ, McLaughlin JP (2012) Expression of HIV-Tat protein is associated with learning and memory deficits in the mouse. Behav Brain Res 229:48-56. CrossRef Medline

Cavaliere F, Urra O, Alberdi E, Matute C (2012) Oligodendrocyte differentiation from adult multipotent stem cells is modulated by glutamate. Cell Death Dis 3:e268. CrossRef Medline

Contreras X, Bennasser Y, Chazal N, Moreau M, Leclerc C, Tkaczuk J, Bahraoui E (2005) Human immunodeficiency virus type 1 Tat protein induces an intracellular calcium increase in human monocytes that requires DHP receptors: involvement in TNF-alpha production. Virology 332:316-328. CrossRef Medline

De Biase LM, Nishiyama A, Bergles DE (2010) Excitability and synaptic communication within the oligodendrocyte lineage. J Neurosci 30:36003611. CrossRef Medline

Deng W, Rosenberg PA, Volpe JJ, Jensen FE (2003) Calcium-permeable AMPA/kainate receptors mediate toxicity and preconditioning by oxygen-glucose deprivation in oligodendrocyte precursors. Proc Natl Acad Sci U S A 100:6801-6806. CrossRef Medline

Dennis J, White MA, Forrest AD, Yuelling LM, Nogaroli L, Afshari FS, Fox MA, Fuss B (2008) Phosphodiesterase-Ialpha/autotaxin's MORFO domain regulates oligodendroglial process network formation and focal adhesion organization. Mol Cell Neurosci 37:412-424. CrossRef Medline

Derkach V (2011) Zooming in on AMPA receptor regulation by CaMKII. Nat Neurosci 14:674-675. CrossRef Medline

Derkach V, Barria A, Soderling TR (1999) $\mathrm{Ca}^{2+} /$ calmodulin-kinase II enhances channel conductance of alpha-amino-3-hydroxy-5-methyl-4isoxazolepropionate type glutamate receptors. Proc Natl Acad Sci U S A 96:3269-3274. CrossRef Medline

Dubois-Dalcq M, Behar T, Hudson L, Lazzarini RA (1986) Emergence of three myelin proteins in oligodendrocytes cultured without neurons. J Cell Biol 102:384-392. CrossRef Medline

El-Hage N, Gurwell JA, Singh IN, Knapp PE, Nath A, Hauser KF (2005) Synergistic increases in intracellular $\mathrm{Ca}^{2+}$, and the release of MCP-1, RANTES, and IL- 6 by astrocytes treated with opiates and HIV-1 Tat. Glia 50:91-106. CrossRef Medline

El-Hage N, Wu G, Wang J, Ambati J, Knapp PE, Reed JL, Bruce-Keller AJ, Hauser KF (2006) HIV-1 Tat and opiate-induced changes in astrocytes promote chemotaxis of microglia through the expression of MCP-1 and alternative chemokines. Glia 53:132-146. CrossRef Medline

El-Hage N, Bruce-Keller AJ, Knapp PE, Hauser KF (2008a) CCL5/RANTES gene deletion attenuates opioid-induced increases in glial CCL2/MCP-1 immunoreactivity and activation in HIV-1 Tat-exposed mice. J Neuroimmune Pharmacol 3:275-285. CrossRef Medline
El-Hage N, Bruce-Keller AJ, Yakovleva T, Bazov I, Bakalkin G, Knapp PE, Hauser KF (2008b) Morphine exacerbates HIV-1 Tat-induced cytokine production in astrocytes through convergent effects on $\left[\mathrm{Ca}^{2+}\right]_{\mathrm{i}}, \mathrm{NF}-\kappa \mathrm{B}$ trafficking and transcription. PLoS One 3:e4093. CrossRef Medline

Fitting S, Ignatowska-Jankowska BM, Bull C, Skoff RP, Lichtman AH, Wise LE, Fox MA, Su J, Medina AE, Krahe TE, Knapp PE, Guido W, Hauser KF (2013) Synaptic dysfunction in the hippocampus accompanies learning and memory deficits in human immunodeficiency virus type-1 Tat transgenic mice. Biol Psychiatry 73:443-453. CrossRef Medline

Fitting S, Knapp PE, Zou S, Marks WD, Bowers MS, Akbarali HI, Hauser KF (2014) Interactive HIV-1 Tat and morphine-induced synaptodendritic injury is triggered through focal disruptions in $\mathrm{Na}^{+}$influx, mitochondrial instability, and $\mathrm{Ca}^{2+}$ overload. J Neurosci 34:12850-12864. CrossRef Medline

Follett PL, Deng W, Dai W, Talos DM, Massillon LJ, Rosenberg PA, Volpe JJ, Jensen FE (2004) Glutamate receptor-mediated oligodendrocyte toxicity in periventricular leukomalacia: a protective role for topiramate. J Neurosci 24:4412-4420. CrossRef Medline

Gallo V, Ghiani CA (2000) Glutamate receptors in glia: new cells, new inputs and new functions. Trends Pharmacol Sci 21:252-258. CrossRef Medline

Hahn YK, Podhaizer EM, Hauser KF, Knapp PE (2012) HIV-1 alters neural and glial progenitor cell dynamics in the central nervous system: coordinated response to opiates during maturation. Glia 60:1871-1887. CrossRef Medline

Hahn YK, Podhaizer EM, Farris SP, Miles MF, Hauser KF, Knapp PE (2015) Effects of chronic HIV-1 Tat exposure in the CNS: heightened vulnerability of males versus females to changes in cell numbers, synaptic integrity, and behavior. Brain Struct Funct 220:605-623. CrossRef Medline

Haughey NJ, Mattson MP (2002) Calcium dysregulation and neuronal apoptosis by the HIV-1 proteins Tat and gp120. J Acquir Immune Defic Syndr 31 [Suppl 2]:S55-S61. Medline

Haughey NJ, Nath A, Mattson MP, Slevin JT, Geiger JD (2001) HIV-1 Tat through phosphorylation of NMDA receptors potentiates glutamate excitotoxicity. J Neurochem 78:457-467. CrossRef Medline

Hauser KF, McLaughlin PJ, Zagon IS (1989) Endogenous opioid systems and the regulation of dendritic growth and spine formation. J Comp Neurol 281:13-22. CrossRef Medline

Hauser KF, Hahn YK, Adjan VV, Zou S, Buch SK, Nath A, Bruce-Keller AJ, Knapp PE (2009) HIV-1 Tat and morphine have interactive effects on oligodendrocyte survival and morphology. Glia 57:194-206. CrossRef Medline

Hollmann M, Heinemann S (1994) Cloned glutamate receptors. Annu Rev Neurosci 17:31-108. CrossRef Medline

Hudmon A, Schulman H (2002) Structure-function of the multifunctional Ca2+/calmodulin-dependent protein kinase II. Biochem J 364:593-611. CrossRef Medline

Imgrund S, Hartmann D, Farwanah H, Eckhardt M, Sandhoff R, Degen J, Gieselmann V, Sandhoff K, Willecke K (2009) Adult ceramide synthase 2 (CERS2)-deficient mice exhibit myelin sheath defects, cerebellar degeneration, and hepatocarcinomas. J Biol Chem 284:33549-33560. CrossRef Medline

Itoh T, Beesley J, Itoh A, Cohen AS, Kavanaugh B, Coulter DA, Grinspan JB, Pleasure D (2002) AMPA glutamate receptor-mediated calcium signaling is transiently enhanced during development of oligodendrocytes. J Neurochem 81:390-402. CrossRef Medline

Jayadev S, Yun B, Nguyen H, Yokoo H, Morrison RS, Garden GA (2007) The glial response to CNS HIV infection includes p53 activation and increased expression of p53 target genes. J Neuroimmune Pharmacol 2:359-370. CrossRef Medline

Johnson TP, Patel K, Johnson KR, Maric D, Calabresi PA, Hasbun R, Nath A (2013) Induction of IL-17 and nonclassical T-cell activation by HIV-Tat protein. Proc Natl Acad Sci U S A 110:13588-13593. CrossRef Medline

Káradóttir R, Cavelier P, Bergersen LH, Attwell D (2005) NMDA receptors are expressed in oligodendrocytes and activated in ischaemia. Nature 438: 1162-1166. CrossRef Medline

Kavanaugh B, Beesley J, Itoh T, Itoh A, Grinspan J, Pleasure D (2000) Neurotrophin-3 (NT-3) diminishes susceptibility of the oligodendroglial lineage to AMPA glutamate receptor-mediated excitotoxicity. J Neurosci Res 60:725-732. CrossRef Medline

Kim BO, Liu Y, Ruan Y, Xu ZC, Schantz L, He JJ (2003) Neuropathologies in transgenic mice expressing human immunodeficiency virus type 1 Tat 
protein under the regulation of the astrocyte-specific glial fibrillary acidic protein promoter and doxycycline. Am J Pathol 162:1693-1707. CrossRef Medline

Kim HJ, Martemyanov KA, Thayer SA (2008) Human immunodeficiency virus protein Tat induces synapse loss via a reversible process that is distinct from cell death. J Neurosci 28:12604-12613. CrossRef Medline

King JE, Eugenin EA, Buckner CM, Berman JW (2006) HIV tat and neurotoxicity. Microbes Infect 8:1347-1357. CrossRef Medline

Kirischuk S, Scherer J, Möller T, Verkhratsky A, Kettenmann H (1995) Subcellular heterogeneity of voltage-gated $\mathrm{Ca} 2+$ channels in cells of the oligodendrocyte lineage. Glia 13:1-12. CrossRef Medline

Knapp PE, Hauser KF (1996) mu-Opioid receptor activation enhances DNA synthesis in immature oligodendrocytes. Brain Res 743:341-345. CrossRef Medline

Knapp PE, Bartlett WP, Skoff RP (1987) Cultured oligodendrocytes mimic in vivo phenotypic characteristics: cell shape, expression of myelinspecific antigens, and membrane production. Dev Biol 120:356-365. CrossRef Medline

Kristensen AS, Jenkins MA, Banke TG, Schousboe A, Makino Y, Johnson RC, Huganir R, Traynelis SF (2011) Mechanism of Ca2+/calmodulindependent kinase II regulation of AMPA receptor gating. Nat Neurosci 14:727-735. CrossRef Medline

Li W, Huang Y, Reid R, Steiner J, Malpica-Llanos T, Darden TA, Shankar SK, Mahadevan A, Satishchandra P, Nath A (2008) NMDA receptor activation by HIV-Tat protein is clade dependent. J Neurosci 28:12190-12198. CrossRef Medline

Liu Y, Jones M, Hingtgen CM, Bu G, Laribee N, Tanzi RE, Moir RD, Nath A, He JJ (2000) Uptake of HIV-1 tat protein mediated by low-density lipoprotein receptor-related protein disrupts the neuronal metabolic balance of the receptor ligands. Nat Med 6:1380-1387. CrossRef Medline

Lokensgard JR, Hu S, Hegg CC, Thayer SA, Gekker G, Peterson PK (2001) Diazepam inhibits HIV-1 Tat-induced migration of human microglia. J Neurovirol 7:481-486. CrossRef Medline

Matute C (2011) Glutamate and ATP signalling in white matter pathology. J Anat 219:53-64. CrossRef Medline

Matute C, Alberdi E, Ibarretxe G, Sánchez-Gómez MV (2002) Excitotoxicity in glial cells. Eur J Pharmacol 447:239-246. CrossRef Medline

Matute C, Domercq M, Sánchez-Gómez MV (2006) Glutamate-mediated glial injury: mechanisms and clinical importance. Glia 53:212-224. CrossRef Medline

McDonald JW, Levine JM, Qu Y (1998) Multiple classes of the oligodendrocyte lineage are highly vulnerable to excitotoxicity. Neuroreport 9:27572762. CrossRef Medline

Micu I, Jiang Q, Coderre E, Ridsdale A, Zhang L, Woulfe J, Yin X, Trapp BD, McRory JE, Rehak R, Zamponi GW, Wang W, Stys PK (2006) NMDA receptors mediate calcium accumulation in myelin during chemical ischaemia. Nature 439:988-992. Medline

Milstein AD, Nicoll RA (2008) Regulation of AMPA receptor gating and pharmacology by TARP auxiliary subunits. Trends Pharmacol Sci 29: 333-339. CrossRef Medline

Montag D, Giese KP, Bartsch U, Martini R, Lang Y, Blüthmann H, Karthigasan J, Kirschner DA, Wintergerst ES, Nave KA, et al. (1994) Mice deficient for the myelin-associated glycoprotein show subtle abnormalities in myelin. Neuron 13:229-246. CrossRef Medline

Nath A, Haughey NJ, Jones M, Anderson C, Bell JE, Geiger JD (2000) Synergistic neurotoxicity by human immunodeficiency virus proteins Tat and gp120: protection by memantine. Ann Neurol 47:186-194. CrossRef Medline

Perry SW, Barbieri J, Tong N, Polesskaya O, Pudasaini S, Stout A, Lu R, Kiebala M, Maggirwar SB, Gelbard HA (2010) Human immunodeficiency virus-1 Tat activates calpain proteases via the ryanodine receptor to enhance surface dopamine transporter levels and increase transporterspecific uptake and $V_{\max }$. J Neurosci 30:14153-14164. CrossRef Medline

Popko B, Puckett C, Lai E, Shine HD, Readhead C, Takahashi N, Hunt SW 3rd, Sidman RL, Hood L (1987) Myelin deficient mice: expression of myelin basic protein and generation of mice with varying levels of myelin. Cell 48:713-721. CrossRef Medline

Power C, Hui E, Vivithanaporn P, Acharjee S, Polyak M (2012) Delineating HIV-associated neurocognitive disorders using transgenic models: the neuropathogenic actions of Vpr. J Neuroimmune Pharmacol 7:319-331. CrossRef Medline
Reynolds ES (1963) The use of lead citrate at high $\mathrm{pH}$ as an electron-opaque stain in electron microscopy. J Cell Biol 17:208-212. CrossRef Medline

Rumbaugh JA, Bachani M, Li W, Butler TR, Smith KJ, Bianchet MA, Wang T, Prendergast MA, Sacktor N, Nath A (2013) HIV immune complexes prevent excitotoxicity by interaction with NMDA receptors. Neurobiol Dis 49:169-176. CrossRef Medline

Salter MG, Fern R (2005) NMDA receptors are expressed in developing oligodendrocyte processes and mediate injury. Nature 438:1167-1171. CrossRef Medline

Sánchez-Gómez MV, Alberdi E, Ibarretxe G, Torre I, Matute C (2003) Caspasedependent and caspase-independent oligodendrocyte death mediated by AMPA and kainate receptors. J Neurosci 23:9519-9528. Medline

Sattentau QJ, Dalgleish AG, Weiss RA, Beverley PC (1986) Epitopes of the CD4 antigen and HIV infection. Science 234:1120-1123. CrossRef Medline

Sheng WS, Hu S, Hegg CC, Thayer SA, Peterson PK (2000) Activation of human microglial cells by HIV-1 gp41 and Tat proteins. Clin Immunol 96:243-251. CrossRef Medline

Staprans S, Marlowe N, Glidden D, Novakovic-Agopian T, Grant RM, Heyes M, Aweeka F, Deeks S, Price RW (1999) Time course of cerebrospinal fluid responses to antiretroviral therapy: evidence for variable compartmentalization of infection. AIDS 13:1051-1061. CrossRef Medline

Tan IL, McArthur JC (2012) HIV-associated neurological disorders: a guide to pharmacotherapy. CNS Drugs 26:123-134. CrossRef Medline

Trapp BD, Quarles RH, Suzuki K (1984) Immunocytochemical studies of quaking mice support a role for the myelin-associated glycoprotein in forming and maintaining the periaxonal space and periaxonal cytoplasmic collar of myelinating Schwann cells. J Cell Biol 99:594-606. CrossRef Medline

Urbinati C, Bugatti A, Giacca M, Schlaepfer D, Presta M, Rusnati M (2005a) alpha(v)beta3-integrin-dependent activation of focal adhesion kinase mediates NF-kappaB activation and motogenic activity by HIV-1 Tat in endothelial cells. J Cell Sci 118:3949-3958. CrossRef Medline

Urbinati C, Mitola S, Tanghetti E, Kumar C, Waltenberger J, Ribatti D, Presta M, Rusnati M (2005b) Integrin alphavbeta3 as a target for blocking HIV-1 Tat-induced endothelial cell activation in vitro and angiogenesis in vivo. Arterioscler Thromb Vasc Biol 25:2315-2320. CrossRef Medline

Urbinati C, Ravelli C, Tanghetti E, Belleri M, Giacopuzzi E, Monti E, Presta M, Rusnati M (2012) Substrate-immobilized HIV-1 Tat drives VEGFR2/alpha(v)beta(3)-integrin complex formation and polarization in endothelial cells. Arterioscler Thromb Vasc Biol 32:e25-e34. CrossRef Medline

Waggener CT, Dupree JL, Elgersma Y, Fuss B (2013) CaMKII $\beta$ regulates oligodendrocyte maturation and CNS myelination. J Neurosci 33:1045310458. CrossRef Medline

Wang T, Jiang Z, Hou W, Li Z, Cheng S, Green LA, Wang Y, Wen X, Cai L, Clauss M, Wang Z (2014) HIV Tat protein affects circadian rhythmicity by interfering with the circadian system. HIV Med 15:565-570. CrossRef Medline

Williams R, Yao H, Dhillon NK, Buch SJ (2009) HIV-1 Tat co-operates with IFN-gamma and TNF-alpha to increase CXCL10 in human astrocytes. PLoS One 4:e5709. CrossRef Medline

Xiao H, Neuveut C, Tiffany HL, Benkirane M, Rich EA, Murphy PM, Jeang KT (2000) Selective CXCR4 antagonism by Tat: implications for in vivo expansion of coreceptor use by HIV-1. Proc Natl Acad Sci U S A 97: 11466-11471. CrossRef Medline

Yilmaz A, Svennerholm B, Hagberg L, Gisslén M (2006) Cerebrospinal fluid viral loads reach $<2$ copies/ml in HIV-1-infected patients with effective antiretroviral therapy. Antivir Ther 11:833-837. Medline

Zhang Y, Chen K, Sloan SA, Bennett ML, Scholze AR, O'Keeffe S, Phatnani HP, Guarnieri P, Caneda C, Ruderisch N, Deng S, Liddelow SA, Zhang C, Daneman R, Maniatis T, Barres BA, Wu JQ (2014) An RNA-sequencing transcriptome and splicing database of glia, neurons, and vascular cells of the cerebral cortex. J Neurosci 34:11929-11947. CrossRef Medline

Zhu X, Yao H, Peng F, Callen S, Buch S (2009) PDGF-mediated protection of SH-SY5Y cells against Tat toxin involves regulation of extracellular glutamate and intracellular calcium. Toxicol Appl Pharmacol 240:286291. CrossRef Medline

Zou S, Fitting S, Hahn YK, Welch SP, El-Hage N, Hauser KF, Knapp PE (2011) Morphine potentiates neurodegenerative effects of HIV-1 Tat through actions at $\mu$-opioid receptor-expressing glia. Brain 134:36163631. CrossRef Medline 